\title{
Corporate Governance and Risk Disclosure Quality: Tunisian Evidence
}

\author{
Issal Haj Salem \\ IHEC Carthage, University of Carthage, LIGUE, Tunisia \\ Email: issal.hajsalem@gmail.com \\ Salma Damak Ayadi \\ IHEC Carthage, University of Carthage, LIGUE, Tunisia \\ Email: salmadamak@yahoo.fr \\ Khaled Hussainey \\ University of Portsmouth, Portsmouth, UK \\ Email: khaled.hussainey@port.ac.uk
}

\begin{abstract}
Purpose: We investigate the potential influence of corporate governance mechanisms on risk disclosure quality in Tunisia.

Methodology: We examine 152 annual reports of Tunisian non-financial-listed firms during 2008-2013.We use the manual content analysis method to measure the risk disclosure quality.

Findings: We find that the quality of risk disclosure in Tunisian companies is relatively low. We also find that the quality of risk disclosure is positively associated with institutional ownership, board independence, the presence of women on the board, the presence of family members on the board, and the independence of audit committee. Managerial ownership has a negative effect on risk disclosure quality. Finally, we find that the revolution decreases the influence of concentration ownership, government ownership, family ownership and audit committee size on risk disclosure quality.

\section{Originality/value:}

Using a comprehensive set of corporate governance mechanisms and a new measure for risk disclosure quality in Tunisia, we provide the first empirical evidence on the impact of corporate governance mechanisms on risk disclosure quality in a developing country. Our study has theoretical and practical implications for both developed and developing countries.
\end{abstract}

Keywords: Risk disclosure quality, corporate governance, content analysis, annual reports, Tunisian firms 


\section{Introduction}

Transparency has attracted increased attention following the major scandals and corporate collapses of the early 2000s and the global financial crisis. These collapses emphasized the need for information and good corporate governance. Besides, there is an increasing demand for high quality information for investors' decision-making process (Miihkinen, 2013). Tunisia was not immune from these events and gives more importance to transparency and good corporate governance practices.

Accounting literature emphasized the importance of the risk disclosure to fulfil the demand of their stakeholders to assess the company's risk profile and the firm market value (e.g. Abraham et al., 2012; Miihkinen, 2013). Risk disclosure may be affected by governance structures (Abraham and Cox, 2007). Hence, there is a need for research to examine the influence of corporate governance mechanisms on risk disclosure (Said Mokhtar and Mellett, 2013). Although extensive literature has examined the impact of governance on disclosure, little has examined the impact of governance on risk disclosure in general and in developing countries in particular.

In addition, there is a need for more risk disclosure especially during the crisis or the challenges that a company may undergo, in order to assess its future performance and to ensure the protection of their wealth. Therefore, understanding the determinants of risk disclosure represents relevant information for standard-setters. Besides, there were calls for further research on the impact of corporate governance on risk disclosure (Khlif and Hussainey, 2016). Our paper replied to this call for research. It worth noting that prior research uses the quantity of disclosure as a proxy for disclosure quality. However, literature shows that disclosure quality is more important than disclosure quantity (Marston and Shrives, 1991; Beretta and Bozzolan, 2004). This motivates us to measure risk disclosure quality and then to examine the impact of governance mechanisms on this type of disclosure.

Tunisia provides a unique country context to analyze the impact of governance on risk disclosure quality. It was influenced by the financial scandals around the world as well as the "Arab Spring" that was sparked at the beginning of 2011. This public demonstration against the country's political system has doubtless severely affected also the economic development and 
consequently Tunisian firms. We consider that it is crucial, in such context, to reassure investors about the risk that may incur. Hence, risk disclosure becomes increasingly useful to keep corporate survival and ensure especially investors about their wealth; these risks related information should be of high quality to help investors in their decision-making process.

In addition, it is necessary to implement good governance mechanisms, responding to a democratic regime, characterized by accountability and clearly defined responsibilities, and to ensure satisfactory transparency and restore confidence towards investors. That is why new debates took place in Tunisia after the revolution in order to reinforce this corporate governance structure and to assure better transparency. The mentioned scenario of events and debate on risk disclosure motivates us to undertake this study. Indeed, the purpose of this study is to investigate the practices of risk disclosure in Tunisia and the impact of the corporate governance structure on risk disclosure quality. In addition, we test whether the revolution has an impact on this relationship.

Our study has several contributions. We examine risk disclosure quality in an emerging market, where investor confidence was considerably damaged by the revolution of 2011. Therefore, we introduced a new measure of risk disclosure quality on Tunisian annual reports. We also contribute by examining the impact of governance mechanisms Tunisian companies' risk disclosure quality in their annual reports. We also consider examining the impact of a period of political crisis on the disclosure-governance relation.

The empirical findings revealed that the risk disclosure quality is positively and significantly associated with institutional, independence of the directors, the presence of women on the board, the presence of family members on the board and the independence of audit committee. However, managerial ownership has a negative effect on risk disclosure quality. In addition, the results show that the revolution has a negative impact on the association between risk disclosure quality and government ownership, family ownership. Moreover, the revolution decreases also the influence of concentration ownership, government ownership, family ownership and audit committee size on the quality of risk disclosure. However, no change in the relationship between the quality of risk disclosure and the remainder corporate governance mechanisms.

The remainder of the paper proceeds as follows. Section 2 presents the corporate governance and risk disclosure in Tunisia. Section 3 reviews the literature and develops hypotheses. Section 4 discusses the methodology. Empirical analysis and the discussion are presented in Sections 5 and 6. Section 7 concludes.

\section{Corporate Governance and Risk disclosure in Tunisia}

\subsection{Corporate governance}

Tunisia has been affected by the financial scandals like Enron (2001), Vivendi (2002), Parmalat (2003), and the 2008 crisis but especially by the collapse experienced by Batam (leader in mass distribution particularly in appliances) at the end of 2002. This bankruptcy was the result of considerable financial commitments of the company, without any warning from its auditor. The confidence crisis exploded with the case of BATAM gave birth to the Law No. 2005-96[1] related to the security of financial relations. This law highlighted two fundamental aspects: strengthening corporate governance rules and the improvement of the quality of external 
auditor. The discussions on the concept of corporate governance in Tunisia started in the late 90s. In 2004, the debates officially took place through two institutions worrying about studying the governance characteristics, in Tunisia and overseas, in order to identify the areas needing improvement and specific recommendations to the Tunisian context. Hence, the Arab Institute of Business Managers (IACE) held in October 2004 a conference about "Corporate Governance in Tunisia: Responsibility and Ethics". Then a Conference on Governance and Development took place at the end of 2005 discussing the topic "Towards Better Governance for Development in the Maghreb". In 2006, the French Institute of Directors (IFA) held another international conference held in Tunisia to investigate "Governance, Performance and Value Creation: Challenges of the Tunisian company". Therefore, after several investigations, the first Tunisian code of good corporate governance practices has been developed by the Tunisian Center of corporate governance (CTGE)[2]. This document was produced with the support of the Center for International Private Enterprise (CIPE) and in collaboration with the OECD and IFC (International Finance Corporation).

However, the revolution of 14 January 2011 has raised a problem of good governance and several shortcomings in Tunisian companies. Therefore, new debates have been created to strengthen the governance practices already established in the 2008 code and to ensure transparency and regain investor confidence. Indeed, the political authorities became better aware of the importance of the implementation of good governance system in Tunisia; this system should promote transparency, integrity and the fight against corruption. The 2009' guide was updated in collaboration with the CIPE and with the support of the OECD and the IFC. This update takes into account, besides the family companies, the governance of Limited Liability Companies (SARL). It aims to make an available practical guide to Tunisian companies to help them to strengthen their knowledge regarding corporate governance and to assist them in setting up a reliable governance system that preserves all stakeholders' interest. This code has focused on the structure and responsibilities of the board, the need for an internal audit, the transparency and the role of auditors, the managers' privileges, the stakeholders' relationship, the practices of good governance in family companies, the managers' role, the ethics and the governance of SARL.

\subsection{Risk disclosure}

The meaning of risk has been evolving through times. In pre-modern society, the risk was related to the act of nature and perceived as uncontrollable. However, following the industrial revolution and the invention of probabilities and mathematical methodology, the perception of risk has changed. In an introduction to factor analysis of risk information, Jones (2006; p. 8) has defined risk as "The probable frequency and probable magnitude of future loss". This definition includes three concepts; the probability of risk, the frequency and magnitude of risk and the universality of risk[3]. The following definition is applicable regardless of the nature and the context of risk.

Then the risk, referring to the modernist view, in contrast with the pre-modern era, includes both the positive and negative outcomes of events (Linsley and Shrives, 2006). That is why it can be defined as "any opportunity or prospect, or of any hazard, danger, harm, threat or exposure, that has already impacted upon the company or may impact upon the company in the future or of the management of any such opportunity, prospect, hazard, harm, or threat or exposure" (Linsley and Shrives, 2006 ; p. 402). In other words, the risk is when we take a 
chance at something that either can turn out better for us or could result in a negative outcome. Therefore, risk can be a "downside risk"[4] or a "volatility risk" [5].

In addition, the concept of risk was related to business strategies, objectives, and economic performance. As such, risk is referred to as follows: "uncertain future events which could influence the achievement of the organization's strategic, operational and financial objectives. The dimensions of risk also include the impact on an organization's reputation, even "loss of legitimacy" from activities deemed unacceptable to the community" (IFAC 1999; p. 6). In the same view, King II has defined risk as "uncertain future events that could influence the achievement of a company's objectives” (King Committee, 2002, p. 30).

Consequently, different definitions have emerged in the literature. The most popular definition is that mentioned in FRS 5 (p. 9)[6] that defines risk as "uncertainty as the amount of benefit. The term includes both potential for gain and exposure to loss". This definition was also suggested by professional reports like ICAEW (1997), CICA (2002) and IASB (2005). This definition of risk will be further incorporated into the risk disclosure the definition followed in our study.

After defining risk we can relate risk disclosure to the dissemination of any information that can make the reader able to know about "any opportunity or prospect, or of any hazard, danger, harm, threat or exposure, that has already impacted upon the company or may impact upon the company in the future or of the management of any such opportunity, prospect, hazard, harm, threat or exposure" (Linsley and Shrives, 2006; p. 389). Also, Beretta and Bozzolan (2004, p. 269) defined risk disclosures as "a communication of information concerning firms' strategies, characteristics, operations, and other external factors that have the potential to affect expected results".

\subsection{The state of disclosure on Tunisian annual reports}

The regulatory bodies in Tunisia began to introduce reforms regarding disclosure from the ninety years and gave it more attention in recent years. Therefore, the process of disclosure by listed Tunisian firms is framed through:

* The accounting system of Tunisian companies

In December 1996, Tunisia has managed to adopt standards in harmony with those of the IASB and this by the promulgation of the Law No. 96-112 of 30 December 1996 concerning companies accounting system. The Tunisian accounting reform through the accounting system has the main objective to improve the usefulness of financial reporting in the stock market (Belgacem and Omri, 2014). This system fills deficiencies of the PCG (1968) and aims to integrate into the world economy and improve the quality of financial information disclosed by the Tunisian companies. It requires Tunisian companies to comply with its standards and the periodic disclosure of financial statements but also gives them the opportunity to broadcast other information that contributes to the enrichment of these financial statements. Indeed, paragraph 83 of Decree No. 96-2459 of 30 December 1996 approving the conceptual framework of accounting gives importance to non-financial information such as social, environmental, and technological. However, we note that compared to the financial statements which benefit of a rich legal framework, there are no comparable standards covering the content 
and the additional information that can be disclosed in the annual report (Chakroun and Matoussi, 2010).

* The 94-117 law concerning the reorganization of the financial market

Following the Law of 14 November 1994, new specialized and independent structures have been established in the Tunisian financial market. These structures are the Stock Exchange of Tunis (BVMT), the Financial Market Council (CMF)[7], Interprofessional Company of Compensation and Securities Deposit (STICODEVAM) and the Market Guarantee Fund (FGM). In addition, this law aimed to strengthen the rules of transparency and security and improve information for the investors and the protection of savings. However aiming to a greater economic openness to the global markets and the need for new foreign investors, some reforms have been made by the Law 205-96 of 18 October 2005 mainly aim to strengthen the financial security and the credibility of the information provided by companies. In addition, this law mentioned the content of the annual report. Indeed, Article 3 (new)[8] states that the "annual report on the company's management should include the information laid down by the Financial Market Council and particularly, a presentation of activities' results, their expected development and eventually the changes in the methods of the development and the presentation of financial statements, as well as elements of internal control".

We also note that this article merely mentions the content of the annual report, unlike the financial statements, as an indicative and not compulsory basis. In fact, the Tunisian listed firms have only the obligation to file their financial statements[9] that must be prepared in accordance with rules and standards of the Tunisian accounting system. Then these statements should also be given to the BVMT and CMF[10].

\section{* The Commercial Companies Code (CSC)}

According to article 201 of CSC, we find that the Board of Directors has to prepare an annual report and submit it to the General Assembly. However, this article fails to specify the content of this report. In other words, the legal obligations relating to the annual report are reduced to submission of a "detailed" annual report and it remains fully at the discretion of managers to determine the content of this report (Yaich, 2004).

* The settlement of Financial Market Council regarding the public offering

The main missions of the Financial Market Council (CMF) are the regulation of the financial market, the control of financial information, the financial market supervision, the sanctions imposed for violations to regulations and the national and international cooperation and communication with its environment. Among the regulations regarding Tunisian companies making public offerings, there are the Article 3 (new) of Law No. 2005-96 of 18 October 2005 and the Article 44 (new) of the Decree of the Minister of Finance September 17, 2008. They provide mainly a presentation on the results of activities, their foreseeable evolution and changes in methods of preparation and presentation of financial statements (Diouani and Khlifi, 2013). However, it should be noted that Article 44 CMF took the initiative to frame the disclosure of information in the annual reports by presenting in an annex a standard management report model containing all the required information provided within defined 
sections and allowed some discretion to the company to include in its annual report other information in addition to those mentioned. Nevertheless, it is necessary to point out that despite the importance accorded by CMF to clarify disclosures in the annual report, no sanctions in this settlement has been taken into account in case of non-compliance with this disclosure. It just publishes releases to remind companies of the publication of this report[11]. This gives a voluntary and not mandatory scope to such information. This weakness in the sanctions process could explain the limited disclosure by the Tunisian listed companies (Chakroun, 2013). Despite the requirements of the CSC, the corporate accounting system and the Regulation of the Financial Market Council; the disclosure of Tunisian companies in annual reports remains poorly regulated and remains a free decision to managers to choose the information they want to disseminate in their report. It is also the case of risk disclosure in Tunisia, which is considered a voluntary disclosure and remains to the discretion of managers who, according to benefits and costs of risk-related information, will choose to disclose it (or not).

\section{Literature Review and hypotheses development}

Accounting literature has highlighted the importance of the dissemination of risk-related information and the need to improve it. Researchers have investigated the practices of risk disclosure (e.g. Dobler, 2008; Marzouk, 2016). In addition, Deumes (2008) believed that prior research suffers from some limitations especially being focused on the content of risk disclosure rather than its quality. For that, he called future research to examine the risk disclosure taking into account both the quantity and quality dimensions.

Regarding the multi-country studies on corporate risk disclosure, the research of Dobler et al. (2011) is considered as the first cross-country study on the corporate risk disclosure. Researchers examined the determinants of risk disclosure in developed countries (e.g. Lajili, 2009; Elshandidy and Neri, 2015) however the research on the determinants of risk information in developing countries is limited. Researchers examined determinants of risk disclosure in Pakistan (Abid and Shaik, 2015), Malaysia (Amran et al., 2008), India (Saggar and Singh, 2017),Kuwait (Al-Shammari, 2014), Saudi Arabia (e.g. Al-Maghsom et al., 2017 and Alzead and Hussainey, 2017), Bahrain (Mousa and Elamir, 2013), UAE (Hassan, 2009), Egypt (Mokhtar and Mellet, 2013; Baroma, 2014; Marzouk, 2016; Khalil and Maghraby, 2017), Finland (Martikainen et al., 2015), MENA emerging countries (Moumen et al., 2015, 2016), Malawi (Tauringana and Chithambo, 2016), Qatar (Elgammal et al., 2018), China (Elshandidy et al., 2018). Few of these studies had paid attention to the impact of corporate governance mechanisms on corporate risk disclosure. Our paper aims to fill this gap. We measured the quality of risk disclosure for Tunisian non-financial listed companies and investigated the influence of corporate governance mechanisms on the quality of risk disclosure. We focused on ownership structure (concentration ownership, family ownership, foreign investors, managerial ownership, Institutional ownership, Government ownership); the characteristics of the board of directors (independence of the board, CEO Duality, board size, the presence of women on the board, board meeting frequency); the characteristics of the audit committee (expertise of the committee members of audit, the audit committee meeting frequency, audit committee size) and the type of the external auditor. 


\section{Ownership structure}

We have set a number of research hypotheses. The first one is related to the ownership structure. We aim to test the following hypothesis:

\section{H1: The ownership structure affects the risk disclosure quality.}

To test this hypothesis, we have developed sub-hypotheses to examine the impact of different ownership types on risk disclosure. Literature shows that concentrated ownership may enhance the disclosure of relevant information to stakeholders and avoid the discretionary behaviour of the managers (Demsetz and Lehn, 1985). Companies heavily concentrated in capital induce a significant shareholder control on managers (e.g. Agrawal and Mandelker, 1990; Agrawal and Knoeber, 1996). In contrast, companies that have a low concentration capital leaves a considerable margin of maneuvering leaders (Becht, 1997). According to Oliveira et al. (2011), the concentrated ownership structure decreases the agency costs. Indeed owners internalize the benefits of monitoring management, which allow a lower opportunistic behaviour by management (Jensen and Meckling, 1976). Mohobbot (2005) argued that in companies characterized by concentration ownership, managers may disseminate any information about the risk through informal ways such as at meetings, hence it will be a low risk disclosure to stakeholders. Literature also showed that concentration ownership could affect the financial reporting quality (e.g. Bradbury et al., 2006 and Firth et al., 2007). For instance, Firth et al. (2007) showed that the presence of blockholders entails poor quality of financial information. In addition, Miihkinen (2012) showed that concentrated ownership might adversely affect the disclosure of high-quality risk information. Some empirical studies found a negative association between ownership concentration and risk disclosure (Deumes and Knechel, 2008; Said Mokhtar and Mellett, 2013). However, Konishi and Mohobbot (2007) did not found an association between the ownership distribution pattern and risk disclosure. Because of the mixed findings, we hypothesis that:

H1.1: Concentrated ownership negatively affects the risk disclosure quality.

According to the signaling theory, the firms use the disclosure as a signaling tool to the institutional investors in order to meet their information needs. Institutional investors are considered as the most sensitive investors to financial communication and they play a major monitoring role that enhances financial reporting quality and firm performance. Diamond and Verrecchia (1991) and Shleifer and Vishny (1997) showed that a higher proportion of institutional investors tend to reduce information asymmetry and consequently improve the disclosure of private information. Moreover, Healy et al. (1999) indicated that the companies widely disseminating their information attract institutional investors. Literature examines the impact of institutional ownership on disclosure, and offers mixed findings. Studies show a negative impact (Schadewitz and Blevins, 1998), while studies show a positive impact include (e.g. Mangena and Pike, 2005; Barako et al., 2006). Eng and Mak (2003) did not find any impact in their research. Bushee and Noe (2000) found a positive impact of short-term 
institutional share ownership on disclosure, but no impact for long-term institutional share ownership. Risk disclosure literature shows mixed findings. For example, Abraham and Cox (2007) find a negative impact, Elzahar and Hussainey (2012) did not find an impact. Solomon (1999) found that large institutional investors are susceptible to require more information on potentially relevant risk that management may retain for strategic purposes. Therefore, we hypothesis that:

H1.2: Institutional ownership positively affects the risk disclosure quality.

Based on agency theory, the information asymmetry can be reduced when managers have a proportion of equity in the company (Jensen and Meckling, 1976). This is argued by the alignment of the interests of shareholders and managers (Leung and Horwitz, 2004). Literature examined the impact of managerial ownership on disclosure offers mixed findings. A positive impact was found in Warfield et al. (1995), Nagar et al. (2003), Mohd-Nasir and Abdulah (2004), and Leung and Horwitz (2004), while a negative impact is found in Ruland et al. (1990), Eng and Mak (2003) and Sepasi et al. (2016). Huafang and Jianguo (2007), however, did not find any significant impact.

Looking at risk disclosure literature, Deumes and Knechel (2008) found that the extent of voluntary reporting on risk management and internal control and managerial ownership is negatively correlated. We, therefore, hypothesize that:

H1.3: Managerial ownership negatively affects the risk disclosure quality.

According to the agency theory, agency conflicts can arise between the government and the managers because of their divergence of interest. Indeed the aim of the government differs from that of managers in the sense that it is interested in the survival and the interests of the nation more than profit (Mak and Li, 2001). Thereby, corporate disclosure can be a remedy for these agency problems and fight against the opportunistic behaviour of leaders. In addition, according to the stakeholder theory, the powerful stakeholders may exert pressure on managers and force them to disseminate better information. Eng and Mak (2003), Makhija and Patton (2004), Cheng and Courtenay (2006), Huafang and Jianguo (2007) and MohdGhazali (2007) found a positive impact of state ownership on disclosure, while Xiao et al. (2004) find a negative impact. Risk disclosure literature showed a positive impact (Barakat and Hussainey, 2013). We, therefore, hypothesize:

H1.4: Government ownership positively affects the risk disclosure quality.

Charreaux (1985) argues that conflicts of interests and the agency costs between shareholders and managers are almost non-existent in family businesses. This is because owners are often, at the same time, the leaders. Thus, the need for control becomes negligible (Fama and Jensen, 1985). Therefore, the managers (stewards) are viewed as collectively oriented beings primarily concerned with acting in the best interest of the organization and by doing so, in the best interest of the principal (Davis et. al., 1997; Donaldson and Davis, 1991). However, although agency problems related to the separation of ownership and management may be less severe in family 
firms, the agency problems related to conflict of interest among owners are all the more present (Mohobbot et al., 2007). This is due to the fact that family members who are both member of the board of directors and significant shareholders of the company will have direct access to various information and therefore have less need to disclose information they hold. Accordingly, the need for risk disclosure is reduced too.

Chau and Gray (2002) argue that the influence of family ownership on voluntary disclosure differs at different levels of family ownership due to the convergence of interest and management entrenchment effects. They found a positive effect of family ownership on disclosure. They explained that family-controlled firms have little motivation to disclose information because the demand for public disclosure is relatively weak in comparison with firms that have a wider shareholding. They also found that "insider" or family ownership is negatively associated with voluntary disclosure in Hong Kong and Singapore.

Chen and Jaggi (2000) reported that board independence is positively related to financial disclosures and this relationship becomes weaker for family-controlled firms. Gelb (2000) and Ho and Wong (2001) found family ownership negatively affects disclosure quality. We, therefore, hypothesise that:

H1.5: Family ownership negatively affects the risk disclosure quality.

\section{Board Characteristics}

The second set of hypotheses is related to board structure. We aim to test the following hypothesis:

\section{H2: The board of directors affects the risk disclosure quality.}

To test this hypothesis, we have developed sub-hypotheses to examine the impact of different characteristics of the board of directors on the quality of risk disclosure.

The main role of the board of directors is to evaluate the performance of the managers and avoid conflicts of interest. However, achieving this goal requires the independence of the governing body regarding the management of the company. This independence is assessed through the presence of non-executive or outside directors on the board. When referring to the Tunisian Code of good governance, we do not find a precise definition of an independent director. Therefore, we can advance the definition of independent directors through literature. Several authors such as Higgs (2003) and Beekes and Brown (2006) defined the independent nonexecutive directors as the administrators who should not find themselves in a situation that may affect their independence of judgment or place them in a situation of actual or potential conflict of interest, so they should be independent of management.

In addition, others have defined external administrators by excluding the internal ones. Thus, given that inside directors are those who hold a management position in the firm and which can then be of company executives or employees (Sridharan, 1996), so the outside directors are the 
other directors. Literature showed that independent directors may promote the corporate disclosure and may, in turn, gain a good reputation as expert monitors (Samaha et al., 2015). Moreover, their presence reduces the likelihood of financial statement fraud (Beasley, 1996). In addition, inside directors are less effective than outside directors and are unable to punish leaders for fear of losing the personal benefits that they can profit (Jensen, 1993). Indeed, independent directors could reduce the information asymmetry between managers and shareholders by providing more voluntary disclosure (Beasley, 1996). Thus, the appointment of independent directors provide better monitoring of management's behaviour, and so is considered as a way to control agency problems (Allini et al., 2016). Besides, from a resource dependence theory, the non-executive directors are considered as a link between the company and the external environs due to their expertise, prestige and different contacts (Haniffa and Cooke, 2002).

Prior studies on board independence effects on disclosure were inconclusive. Some studies found no impact (Ho and Wong, 2001; Haniffa and Cooke, 2002), while others found a negative impact (Eng and Mak, 2003). A number of studies found a positive impact (e.g. Cheng and Courtenay, 2006; Abraham and Cox, 2007). Risk disclosure literature found a positive impact (e.g. Lajili (2009), Elshandidy and Neri, 2015). Abraham and Cox (2007), Allini et al. (2016), Al-Maghzom et al. (2016), however, found no impact. We, therefore, hypothesis that:

H2.1: Board independence positively affects the risk disclosure quality.

The duality occurs when the chief executive officer (CEO) holds the chair position at the same time. In Tunisia, the separation of the two functions is not an obligation but remains to the discretion of the company. This is mentioned throughout the article 215 of the C.S.C[12] "the statuses of the company may opt for the dissociation between functions of the board directors' chairman and the manager of the company". However, these roles are clearly different in their nature and contributions; we note also that governance codes generally recommend that they have to be realized by different individuals (e.g. Cadbury Report, 1992). In addition, the Tunisian Corporate Governance Guide requires separating the two functions in order to be efficient. CEO duality contributes to a concentration of decision-making that may harm to the board's governance role regarding disclosure policies (Li et al., 2008) and can affect negatively the quality of disclosure and their relevance (e.g. Byard et al., 2006; Firth et al., 2007). The entrenchment theory suggests that a combined leadership structure may promote CEO entrenchment and conflict of interests. Consequently, the CEO duality may reduce the monitoring role and compromises the board independence that may be less motivated to better transparency (Cerbioni and Parbonetti, 2007; Samaha et al., 2015). This is explained by the fact that the CEO has access to private information and he/she is less motivated to share such information with different shareholders or the other members of the board. Hence, the CEO tends to have an opportunistic behaviour and restrict corporate voluntary disclosure (Kim et al., 2007).

Literature on the impact of CEO duality on disclosure offered mixed findings. A number of studies showed no impact (e.g. Cheng and Courtenay, 2006; Al-Shammari and Al-Sultan, 
2010), while others showed a negative impact (e.g. Allegrini and Greco, 2013, Samaha et al., 2015). Haniffa and Cooke (2002), however, found a positive impact of CEO duality on disclosure. Risk disclosure literature did not find an effect of CEO duality on disclosure (Elzahar and Hussainey, 2012 and Mokhtar and Mellett, 2013). Mokhtar and Mellett (2013), however, found a negative impact on mandatory risk disclosure only. Based on the agency entrenchment theories, we set the following hypothesis:

H2.2: CEO duality negatively affects the risk disclosure quality.

In Tunisia, under Article 189 of C.S.C, the board of directors of the public limited companies shall consist of at least three members and at most twelve members. In addition, the Tunisian Corporate Governance Guide recommends a Board of 7 to 9 members. It advocates "a relatively small board to take advantage of different existing expertise and to avoid sinking in endless discussions and approaches, and to be more effective and more responsive in decision making".

Literature showed that large board size increases the efficiency of the board and promotes the disclosure of information (e.g. Cormier et al., 2010). According to the agency theory, the larger boards incorporate a variety of expertise and available resources, which results in more effectiveness in boards' monitoring role (Singh et al., 2004; Hidalgo et al., 2011). In fact, these boards are less likely to be dominated by management thanks to the diverse members' opinions and the power that may exert to supervise managers, which may in turn promote the corporate disclosure (Samaha et al., 2015). In addition, John and Senbet (1998) argued that a large board size may improve the monitoring role due to greater availability and combined effort. Indeed, a large size of the board will allow a high number of members who have financial and accounting background, which could affect managers' voluntary disclosure decisions and extend corporate risk disclosure level (Elzahar and Hussainey, 2012). This is in line with the resource dependency theory, which presumes that large board has a better knowledge and ability to ensure the management of corporate resources (Pfeffer, 1972). However, Elzahar and Hussainey (2012) and Allini et al. (2016) found no impact of board size on risk disclosure, other risk disclosure studies found a positive impact (Allegrini and Greco, 2013; Elshandidy and Neri, 2015) while Al-Maghzom et al. (2016) found a negative impact. Based on agency and resource dependency theories. We hypothesize that:

H2.3: Board size positively affects the risk disclosure quality.

Literature showed that the diversity of experience, background, and attitude allow providing benefits, particularly in corporate governance (Hillman et al., 2007; Srinidhi et al., 2011). Female directors can improve decision making by providing different perspectives and opinions in the decision-making process. Indeed, gender diversity in the board is an effective driver of business performance and can lead to an enrichment of knowledge (Erhardt et al., 2003). Compared to male directors, female directors seem to be more active and they are more likely to attend board meetings and to sit on monitoring committees (Adams and Ferreira, 2009). Women are generally more responsive to crises and more likely to engage in giving than men (Williams, 2003). Literature showed that women provide a more collaborative approach to leadership, which contributes to greater communication between managers and the board, as 
well as stakeholders (Eagly et al., 2003). Ntim et al. (2013) and Allini et al. (2016) found that the presence of women on the board positively affects risk disclosure. Their results were consistent with the research of Ntim et al. (2013). In our paper, we test to see if the presence of women on the board leads to better dissemination of the risk information. We, therefore, hypothesise that:

H2.4: The presence of women on the board positively affects the risk disclosure quality.

Based on the agency and stewardship theories, Ho and Wong (2001), Haniffa and Cooke (2002), Mohd Ghazali and Weetman (2006) found that when listed firms are mostly owned and managed by family members, they are less susceptible to disclose voluntary information. This was justified by the behavior of board members who act and make disclosure decisions according to the desires and needs of the family. In addition, this negative association can be explained by the fact that family members on the board do not have necessary the adequate skills, qualification or experience (Sciascia and Mazzola, 2008) which can have a bad impact on the quantity or quality of disclosure. Al-Shammari (2014), however, found that the presence of family members on the board has not effect on risk disclosure. Based on the agency and stewardship theories, we hypothesize that:

H2.5: The presence of family members on the board negatively affects the risk disclosure quality.

\section{Audit committee characteristics}

The third set of hypotheses is related to audit committee characteristics. We aim to test the following hypothesis:

\section{H3: The audit committee affects the risk disclosure quality}

To test this hypothesis, we have developed sub-hypotheses to examine the impact of different audit committee characteristics on the quality of risk disclosure.

As the board of directors, audit committees that are compound of independent members, of management, are best able to perform their independent oversight functions (Klein, 2002). For instance, Klein (2002) finds a non-linear negative relation between audit committee independence and earnings manipulation. In addition, Persons (2009) stated that firms which make earlier voluntary ethics disclosures were likely to have a larger and more independent audit committee. Regarding risk disclosure, Taylor (2011) and Oliveira et al. (2011) found a positive effect of audit committee independence on corporate risk disclosure. Their findings are consistent with the agency theory. We, therefore, hypothesise that:

H3.1: Audit committee independence positively affects the risk disclosure quality.

A number of studies examine the effect of audit committee size on disclosure (e.g. Carcello and Neal, 2000; Barako et al., 2006). For instance, Barako et al. (2006) found a positive impact, 
while Elzahar and Hussainey (2012) and Al-Maghzom et al., (2016) found no impact. In our study, we follow Kalbers and Fogarty (1993) who argued that a larger audit committee is more likely to improve its status and power within an organization, and enhance the audit quality. In addition, it will be more likely to discover potential problems through sharing of knowledge, and to improve the quality of internal controls, which will make the audit committee more effective in fulfilling its monitoring role (e.g. Barako et al., 2006; Zaman et al., 2011). We, therefore, expect a positive impact of audit committee size on risk disclosure. We hypothesise that:

H3.2: Audit committee size positively affects the risk disclosure quality

\section{The type of auditor}

Agency theory emphasizes that the external audit has an important role to mitigate conflicts of interest between managers and investors (Jensen and Meckling, 1976) and to guarantee the integrity of financial reports (Watts and Zimmerman, 1983). Besides, Kent and Stewart (2008) reported that good governance structure, particularly the type of external auditor, board and audit committee diligence, improves the financial reporting disclosure level. In fact, external auditors play an essential role in disclosure practices of their clients and may exert them a pressure to enhance their transparency (Owusu-Ansah, 1998). Besides, when the annual report is reviewed by a big 4 audit firm, this leads to better report quality and enhances the investors' perception of the voluntary disclosure credibility on internal control (Deumes and Knechel, 2008). Moreover, Khlif and Souissi (2010) pointed up that the big audit firms' role was better highlighted after the financial crisis. They found a positive influence of big audit firms on the corporate disclosure, arguing that they enhance companies to reveal the appropriate information to reflect a good signal to investors. Otherwise, the potential investors may have a wrong signal that may be reflected, in turn, negatively to the investment' decisions.

Risk disclosure literature showed that companies having a Big 4 auditor are more likely to be legitimated by the latter to provide better risk information in their annual reports (Hassan, 2009). In the same sense, Elshandidy et al., (2013) showed that firms with an effective audit environs have incentives to reveal more information about their aggregated and voluntary risk disclosures. In addition, Abid and Shaiq (2015) showed a positive relation between the amount of corporate risk disclosure provided in annual reports of Pakistani listed companies and the type of auditor. However, Elshandidy and Neri (2015) did not find a significant impact of the type of auditor on risk disclosure. We expect that the type of external audit enhance risk disclosure quality. We therefore hypothesize that:

\section{H4: The type of auditor positively affects the risk disclosure quality.}

\section{The corporate risk disclosure and revolution}

Our study examines the risk disclosure in Tunisian annual reports during the period 2008-2013. During this period, Tunisia witnessed the revolution of 14 January 2011 that was sparked in December 2010. The Arab Spring has undoubtedly affected the business environment. For our 
study, we assume that the relationship between corporate governance mechanisms and the level and quality of risk disclosure could be influenced by the revolution. In fact, companies are more exposed to risk after the Tunisian political crisis and we presume that they are susceptible to disclose more risk related information. Such behavior can be explained referring to the signaling and legitimacy theories. In fact, companies at the time of political crisis tend to give signals to investors about the risks and their ability to manage them, in order to reassure the different stakeholders and to legitimate the company's situation. In addition, we can rely on the institutional economic theory to explain the behavior of companies at the time of political changes. For that, through prior studies, Makhaiel and Sherer (2018) investigated through an interpretive approach the impact of socioeconomic factors on the quality of financial reporting in an Egyptian context. They argued that according to the institutional theory a coercive pressure leads regulators to enforce rules in order to have better performance and practices of companies. Hence, they believed that both economic and institutional regulative pressure might affect the quality of financial reporting.

Literature on risk disclosure during crises is limited. Marzouk (2016) examined risk disclosure in the Egyptian context during the Arab spring. He found that Egyptian listed companies disclose more risk related information during crisis. Gulko et al. (2017) found that, the volume of risk disclosure tends to be better during and after the crisis; however risk information is less disseminated during relatively stable moments. In addition, they showed that the nature of risk disclosure information is more generic, symbolic and historical risk information; nevertheless, the quality of risk disclosure tends also to be improved during the financial crisis. Moreover, the findings confirmed that company size has an impact on corporate risk disclosure.

Other studies on risk disclosure over the period of before, during and after the Global Financial Crisis (GFC) are scarce (Abraham et al., 2012). Maffei et al. (2014) found that there is no improvement in risk disclosure in the period of financial crisis. Hassan (2014) also argued that there is a need for more risk disclosure during the crisis and regulators should set strict rules to force companies to disclosure more risk information. Leitner-Hanetseder (2012) found that the quality of risk information increased after the financial crisis. Similarly, Probohudono et al. (2013) found a little increase in business and credit risks in 2009. Ntim et al. (2013) found no impact of financial crisis on risk disclosure. Finally, Meier et al. (1995) also explored the disclosure of political risks before and during the Gulf War in corporate annual reports of US firms operating in Kuwait. They found that companies disclose insufficient war-related information; and highlighted the need of legal requirements to enhance the disclosure of political risks. Based on these studies, we hypothesise that:

\section{H5: The revolution moderate the impact of corporate governance on the risk disclosure quality.}

\section{Methodology}

\subsection{Sample and Data collection}

Our sample is drawn from all non-financial listed companies of the Tunisian Stock Exchange for the period from 2008 to 2013 . The sample covers all industry sectors, except the financial 
ones. We excluded financial firms because the disclosure by financial institutions may differ from disclosure by non-financial companies due to the special nature of their operations, which differs from those of the non-financial firms an also have different disclosure requirements (Schleicher and Walker, 2010). Moreover, the activities of financial firms can generate different types of risk compared to non-financial ones. Risk disclosure literature has also excluded financial firms following prior research (e.g. Elshandidy and Neri (2015), and Marzouk (2016)).

We measured the quality of risk disclosure through the company's annual reports. The collection of annual reports was a labour work due to the unavailability of most annual reports on websites of companies, BVMT, CMF. Therefore, there were collected directly from the CMF, however many annual reports were also unavailable on CMF so there were collected directly from the companies. The annual reports were collected following the listed companies in 2013.

It was crucial to check the existence of outliers on the sample. In fact, the outliers for either parametric or non-parametric estimations can lead to inflated error rates and substantial distortions of parameter and statistic estimates (Zimmerman, 1995, 1998). For that, we carried out a test to check whether our estimations can contain outliers, and then we excluded the extreme observations for our analysis to avoid biased estimations and to enhance the reliability of the results. Excluding extreme observations is consistent with prior literature (e.g., Kothari and Zimmerman, 1995). The current study used the student $t$ test for the residuals to identify the existence of outliers. We removed any observation that present a $t$ greater than 2 in absolute value.

Table 1 summarizes our firms' sample for each year, the number of the excluded outliers and the final sample for our model. In addition, table 2 displays the sample according to industry sectors.

[Insert Table 1 here]

[Insert Table 2 here]

\subsection{Measuring the quality of risk disclosure}

The disclosure quality is considered as a latent variable and many researchers tried to define and measure it, and it continues to be perceived as an abstract concept, which is difficult to measure directly and to have an accurate measure. Beattie et al. (2004, p. 233) affirmed, "Researchers investigating the determinants and consequences of disclosure quality could be wasting their efforts if the primary variable of interest is not being measured with a sufficient degree of accuracy".

In addition, Hopkins (1996) defines disclosure quality as the extent to which current and potential investors can read and interpret the information easily. Moreover, King (1996) perceives disclosure quality as the degree of self-interested bias in the disclosure. It is extremely difficult to measure the management's bias in the information disclosed, as suggested by King's definition. Another definition in this context holds that disclosure quality involves "the firm's ongoing ex-ante commitment to provide disclosure" (Core, 2001, p. 48). The most admitted definition is that disclosure quality is considered as a complex, multi-dimensional, contextsensitive and subjective concept (Beattie et al., 2004). 
We can affirm that there is no universally accepted measure for disclosure quality and particularly risk disclosure and it remains difficult to assess it. In addition, in the Tunisian context there is no study to our knowledge that studied a measure for risk disclosure quality. However, we can refer to the study of Chakroun and Hussainey (2014) which is considered the first study to examine the disclosure quality of financial information in Tunisia. They followed the methodology proposed by Braam and Beest (2013) and measured the quality of disclosure quality through the fundamental qualitative characteristics (relevance and faithful representation) and enhancing qualitative characteristics (understandability, comparability, and timeliness). Hence, in our study, we developed a new measure of risk disclosure quality in the Tunisian context. For that, we defined risk disclosure quality in terms of decision usefulness [13] for stakeholders, and we referred to the conceptual framework of IASB (2010) and notably to the Tunisian firms' accounting system (1997) that presented the qualitative characteristics of information. According to Tunisian firms' accounting system (1997, p. 9) “Qualitative characteristics are the attributes that must be for the financial information conveyed in the financial statements that are essential for ensuring the production and disclosure of useful financial information for decision making". These attributes are understandability, relevance, reliability and comparability.

Indeed, Botosan (2004) argued that disclosure quality could be measured by quality attributes proposed by a regulatory framework. These attributes are understandability, relevance, reliability and comparability. Thereby our risk disclosure quality index is presented in table 3.

\section{[Insert Table 3 here]}

We calculated a sub score for each qualitative attribute. Then we measured an aggregate score for the disclosure quality. Moreover, we used an un-weighted approach to measure the risk disclosure quality for the same reasons advanced in the previous section. In addition to that, the sub scores are weighted equally because on the IASB (2006) framework all attributes are valued equally. Indeed, Chakroun and Hussainey (2014) on their study of the disclosure quality and its determinants in the Tunisian context, they weighted the sub scores of each qualitative attribute equally and consider that is not appropriate to prioritize one attribute over the others weighted relying on the IASB (2006). Moreover, the Tunisian conceptual framework states that a balance must be developed between the different qualitative characteristics. Since the emphasis on a quality attribute will generally be done at the expense of another. It recognizes that it is commonly admitted that the relevance and the reliability are the fundamental qualities; and the comparability and the intelligibility are the secondary ones. However, it points out that it is not easy to determine, in a definitive way, the importance to be accorded to each quality attribute.

In order to ensure the reliability and validity of our scores, we followed Krippendorff (1980) and tested the stability, reproducibility and accuracy of the findings of the content analysis.

Firstly stability also known as intra-rater reliability means that the results should be stable over time and this can be verified if the same coder gets the same results by repeating the same work more than once. In our study this condition was satisfied by recoding a sample of five annual reports later, we do not find significant differences, which confirm the stability of the results within the content analysis. 
In addition, reproducibility is important to confirm the reliability of the classification procedure in the sense of being consistent "different people code the same text in the same way" (Weber 1990, p. 13). Consequently, two other independent researchers were designed and reviewed the content analysis of ten randomly selected annual reports. Each one has read five annual reports separately by using the disclosure quality mentioned earlier. Then, the results from the two researchers were compared with our results. For our study, we used Scott's Pi test to test the inter-reliability[14]. It was calculated by using online statistical software "ReCal" [15]. For five annual reports we found that Scott's Pi scored 0.878, 0.826, 0.838, 0.931 and 1 so a Scott's $\mathrm{Pi}$ average of 0.8946 . Accordingly, this indicates that the quality scores were sufficiently reliable. A result of 0.75 is often considered a satisfactory level of inter-rater reliability (e.g. Linsley and Shrives, 2006; Abraham and Cox, 2007). Given that, our measure of risk disclosure quality was considered sufficiently reliable.

Finally, the "accuracy measures the correspondence of the performance of a method with a given or known standard" Krippendorff (1980, p. 72). In our study, the index of the quality of risk disclosure was constructed with reference to the Tunisian firms' accounting system (1997) and IASB (2010).

\subsection{Research model}

To test our research hypotheses, we use the following regression model:

Qual $=\alpha_{0}+\beta_{1}$ Conc $+\beta_{2}$ Mo $+\beta_{3}$ Inst $+\beta_{4}$ Gov $+\beta_{5}$ Famo $+\beta_{6}$ Outsdr $+\beta_{7}$ Size $\_$bd $+\beta_{8}$ Dual $+\beta_{9}$ Women $+\beta_{10}$ Famd $+\beta_{11}$ Exaud_q $+\beta_{12}$ Size_ac $+\beta_{13}$ Size_comp $+\beta_{14}$ Prof $+\beta_{15}$ Lev $+\beta_{16}$ Liquid + $\beta_{17}$ Divd $+\beta_{18}$ Indus $+\varepsilon$

Where:

$\alpha=$ the intercept.

$\beta_{1}, \ldots, \beta_{21}=$ Regression coefficients.

$\varepsilon=$ Error term

Dependent variables:

Qual = Quality of risk disclosure

Independent variables

Conc: The concentration ownership measured by the proportion of shares owned by major shareholders who hold at least $5 \%$ of equity ownership

Mo: The managerial ownership measured by the proportion of managers and executive directors

Inst: The institutional ownership measured by the proportion of shares owned by institutional investors

Gov: The government ownership measured by the proportion of shares owned by government agencies

Famo: The family ownership measured by the proportion of shares owned by family shareholders

Outsdr: The proportion of independent non-executive directors relative to the Board size

Size_Bd: The number of directors on the board at the end of each year

Dual: Duality of CEO a dummy variable: « $1 »$ if there is a duality, « $0 »$ otherwise

Women: The proportion of women on the board of directors 
Famd: The proportion of family members on the board of directors

Exaud_Q: The type of external auditor, dummy variable 1 if the auditor is one of the Big 4 auditing firms and 0 otherwise.

Size_Ac: The number of committee members

Ind_Ac: The proportion of independent committee members

\section{Control variables}

Size_comp: Natural logarithm of total assets at the end of the year

Prof: Net profit after tax/Shareholders funds

Liquid: Currentassets/currentliabilities

Lev: Total liabilities/ total assets of the firm

Divid: The ratio of the most recent full-year dividends divided by the current share price

Indus: 1 if the firm belongs to consumer services, health, industrials and oil and gas, and 0 otherwise[16].

\section{Empirical analysis and robustness check}

Table 4 provides descriptive statistics for the dependent variable and its attributes. For the risk disclosure quality, it has a mean of 6.89. In addition, we can note that the importance of the qualitative attributes are respectively the faithful representation with a mean of 4.73 and a maximum value of 11 , the understandability with a mean of 1.53 and a maximum value of 6 , the relevance with a mean of 0.45 and a maximum value of 4 and finally the comparability with a mean value of 0.18 and maximum value of 2 . This means that the Tunisian companies from the period 2008-2013 were more susceptible to disseminate risk disclosure information with further explanations than comparable risk information in time and space.

\section{[Insert Table 4 here]}

Table 5 reports descriptive statistics for the independent and control variables. The variables related to the ownership structure show that the Tunisian listed companies are characterized by high concentration ownership with a mean of $68.87 \%$. In addition, the managerial ownership varies significantly between companies with a maximum value of $73.5 \%$, and a minimum value of $0 \%$, which leads as to think about a contradicted behavior regarding the quality of risk disclosure between the companies characterized by high managerial ownership and those with a lower proportion. With regard to the presence of government ownership for some companies is considerable $(74.42 \%)$ compared to others $(0 \%)$. Moreover, the descriptive analysis shows that the majority of listed Tunisian companies are family ones this is concluded through a maximum value of $88.81 \%$ and a mean of $34.61 \%$. Regarding board characteristics, we found that the proportion of independent directors varies highly through companies with a maximum value of $75 \%$ and a minimum value of 0 . Regarding the presence of women on the board is so limited. The presence of the members of the same family on the board is high for some companies it can reach $71.42 \%$ and for a mean of $24.36 \%$.

[Insert Table 5 here] 
Table 6 provides descriptive statistics. Regarding the duality of CEO we note that the most Tunisian listed companies are characterized by a high duality with a percentage of $70 \%$ companies with a board member holding both the Chairman and CEO roles. Regarding the type of the external auditor, we note that most of companies (68.33\%) are not audited by a Big 4 auditor. In addition, the distribution of the sample presents that $48.33 \%$ belongs to consumer services, health, industrials, oil, and gas.

\section{[Insert Table 6 here]}

We used Spearman correlation matrix because the quantitative variables are not normally distributed, except the independence of board' directors. Table 7 shows that there is no multicollinearity problem as no correlation coefficients greater than .80 . We also use VIF (Variance Inflation Factor) as another check for the multicollinearity. A VIF value greater than 10 indicates a case of multicollinearity.

\section{[Insert Table 7 here]}

We used Ramsey test to check for omitted variables. The p value of the Ramsey test is not significant 0.3121 , which confirm that the model is well specified and we conclude the absence of omitted variables.

After that, we examined the homogeneity or heterogeneity of the panel data through a specification panel test (the pooling test) (Hsiao, 1986). We performed a chow test following Beck (2001) who proposed to use the Chow test to compare the pooled and unpooled estimations. We found that the Chow test returns an $\mathrm{F}(27,70)=0.96$ and a prob $>\mathrm{F}=0.5328$. Hence, we should not reject the null hypothesis of homogeneity among individuals. This led us to conclude the non-existence of individual effects and make the estimation through a pooled OLS regression.

Moreover, regarding homoscedasticity, the significant chi2 statistics displayed through the Breush-Pagan test, let us reject the null hypothesis of homoscedasticity for our model. This means that the error terms are heteroscedastic. This issue needs to be corrected to have reliable results. Therefore, it is essential to correct this problem with the method of White (1980).

We examined the normality of the residuals through the Shapiro Wilk test. It is particularly powerful for small samples. The results of the Shapiro Wilk test have p-value greater than 5\% (Prob $>\mathrm{z}=0.74775$ ), which confirm that the residuals are normally distributed.

To test the autocorrelation between residuals we refer to the Wooldridge (2002) test in panel data models. The results (Prob> F= 0.3425) lead us to accept the null hypothesis (no first-order autocorrelation).

However, OLS regression has some limitations. One of its main assumptions is the normality of the dependent variable. However, the dependent variable is a count variable. Hence, when the Y-value is not a continuous variable the OLS regression will not be appropriate and the empirical findings will be biased inefficient and inconsistent. Therefore, Poisson regression 
should be used (Agrawal and Sensarma, 2007). The Poisson regression should be used for rare events as opposed to more common events which tend to be normally distributed. For our study the risk disclosure quality is a count variable and is not normally distributed. However, the Poisson regression is based on the assumption of equidispersion. For that, a deviance test is performed to confirm whether we should run the results using a Poisson regression or a negative binomial regression. Through the deviance test we confirm the assumption of equidispersion (Prob $>$ chi2 $(96)=0.3000)$ which leads us to use the Poisson distribution in our estimations.

A robustness check was necessary in order to ensure the validity of the findings. Hence, we transformed the dependent variable using log. The transformation is helpful to solve some cases such as non-linearity between dependent and independent variables, problem of non-normal distribution, heteroscedasticity, etc. (Cooke, 1998). The results of regression after transformation give us insurance about the validity of the findings of the analysis.

As shown in table 8 the findings of the Poisson regression are almost the same as those of the regression after log transformation. Hence, the similarity of the results allows us to conclude about their robustness.

[Insert Table 8 here]

\section{The corporate risk disclosure and revolution}

We assumed that the revolution has an impact on the association between corporate governance mechanisms and the risk disclosure. Hence, we used interaction terms in order to study this effect. To respond to this aim we introduce a dichotomous variable related to revolution, which takes 0 for the years 2008, 2009 and 2010, and 1 otherwise. Due to the number of variables with the interaction terms, it would be better to separately study the effect of the revolution on the impact of the capital structure, board characteristics and the audit environment on the quality of risk disclosure.

Hence, we tested empirically the three following models and the empirical findings are reported in table 9. We have to note that the deviance test did not support the assumption of equidispertion, therefore the negative binomial regression is performed.

M2:

Qual=revol+conc+REV_CONC+mo+REV_MO+inst+REV_INST+gov+REV_GOV+famo+ REV_FAMO+ size_comp+ prof +lev+liquid+divd+ indus

M3:

Qual $=$ revol + outsdr + REV_OUTSDR + size_bd + REV_SIZEBD +dual +REV_DUAL+ women+REV_WOMEN+ famd+REV_FAMD + size_comp+ prof +lev+liquid+ divd+indus

M4:

Qual=revol+ exaud_q+ REV_EXAUD+ size_ac+ REV_SIZEAC+ ind_ac+ REV_INDAC+ size_comp+ prof +lev+ liquid+ divd+ indus

[Insert Table 9 here] 


\section{Discussions}

\section{Ownership structure}

Regarding concentration ownership, the results show a positive and not significant association which is contradicted with our assumption and with the agency theory. Literature regarding the impact of concentration ownership on CRD is scare, our results are consistent with Konishi and Mohobbot (2007), Oliveira et al. (2011) and Elshandidy and Neri (2015) who revealed an insignificant association. However, our results are inconsistent with Mokhtar and Mellett (2013) who found a negative association. In addition, in term of corporate risk disclosure quality our results are inconsistent with Miihkinen (2012) who revealed that a concentrated ownership might affect negatively the disclosure of high quality risk information.

A negative significant association at the level of $1 \%$ is revealed between managerial ownership and risk disclosure quality, which confirms the hypothesis H1.2. This result is consistent with the information asymmetry theory, the agency theory, and the entrenchment theory. For that, the negative association could be explained according to the agency theory that assumes that such situation enhances the alignment of the interests of shareholders and managers (Leung and Horwitz, 2004). In fact, managers have an opportunistic behavior and are trying to maximize their own wealth. So they will not be motivated to disclose high-quality information because they already can have the information directly (Sepasi et al., 2016). Fama and Jensen (1983, p.309) state that the "diffusion and separation of decision management and control have benefits because they allow valuable knowledge to be used at the points in the decision process where it is most relevant and they help control the agency problems of diffuse residual claims". These findings are consistent with Deumes and Knechel (2008) who found that the extent of voluntary reporting on risk management and internal control and managerial ownership is negatively correlated. Moreover, Marshall and Weetman (2007) and Brown et al. (2011) show that firms characterized by high levels of inside ownership are less susceptible to disclose risk information.

The findings of the impact of institutional ownership on the risk disclosure quality are consistent with the hypothesis H1.3. There are consistent with the signaling theory and agency theory. These results can be justified by the particularity of institutional investors and their sensitive role to the disclosure of relevant risk disclosure. They are considered the most sensitive investors to financial communication. In fact, they are known for their monitoring role that enhances financial reporting quality and firm performance (Chung et al., 2002). According to the agency theory, the institutional investors could limit the discretion behavior of managers and increase risk disclosure (Taylor et al., 2010). Our findings are consistent with Abraham and Cox (2007) but inconsistent with Elzahar and Hussainey (2012) who find no relationship between institutional ownership and risk disclosure. Moreover, Bushee and Noe (2000) and Solomon et al. (2000) have not found a significant relationship between the proportion of longterm horizon institutional ownership and CRD in annual reports.

The findings regarding H1.4 lead us to reject this hypothesis. In fact, we found a negative but no significant relationship between risk disclosure quality and government ownership. The 
results are not consistent with agency theory and stakeholder theory. From a stakeholder theory perspective, state (government) ownership is a key factor influencing corporate governance disclosure; particularly in emerging countries where concentrated ownership structures are widespread (Cornett et al., 2010; Al-Moataz and Hussainey, 2012). Some prior research found that a positive relationship exists between governmental ownership and voluntary disclosure (Baek et al., 2009; Makhija and Patton, 2004). However, the result is consistent with prior research (Barth et al., 1999; Liu et al., 2014) that found a negative association between voluntary disclosure and governmental ownership. Our results are inconsistent with Barakat and Hussainey (2013) who found a positive significant correlation with governmental ownership for banks.

We assumed earlier that family ownership influence negatively the quality of risk disclosure (H1.5). This was justified, referring to agency theory and stewardship theory by the confusion of interests between shareholders and managers, hence between development and profit maximization. The insignificant results can be explained by the different family attitudes among the companies and their position in management. In fact, in companies characterized by an ownership family, the mangers are almost those shareholders, which do not motivate them to disclose risk related information or to care about the quality of this disclosure. However, in companies where the family shareholders do not have an executive position in management, their attitude can differ from those who have a management position. Hence H1.5 is rejected which is inconsistent with agency theory and stewardship theory.

\section{The board structure}

The results of the Poisson regression reveal that the independence of the board of directors has a positive significant impact on the quality of risk disclosure. Hence, we accept the hypothesis H2.1.The results are consistent with the agency theory and dependence resource theory. The positive association is justified by the impact of independent directors to reduce agency costs between managers and shareholders. In fact, the independent directors are able to make an objective opinion on the company's activities and are looking to fulfill their responsibilities and to have a good reputation, which enhances them to disclose more information (Patelli and Principe, 2007). Hence, the outside directors tend to disseminate risk disclosure information in order to signal their credibility, accountability, and transparency to stakeholders. Therefore, more risk disclosure is expected if they are actually carrying out their greater control and monitoring of managerial decisions. In addition, the independent directors are more susceptible to decrease agency conflicts by monitoring the managers and limiting their opportunistic behavior (Fama and Jensen, 1983). This result is consistent with Lajili (2009), Oliveira et al. (2013), Elshandidy et al. (2013), Elshandidy and Neri (2015), and inconsistent with Elgammal et al. (2018) who did not find a significant association.

The findings show a negative but no significant relationship between the board size and the qualityof risk disclosure. This is inconsistent with agency theory and the resource dependency theory. Hence, we reject the hypothesis H2.2. The insignificant association can be related to the difference among companies regarding the board size, which are a minimum of 4 and a maximum of 12. This association is consistent with Elzahar and Hussainey (2012), Allini et al. 
(2016). However, these findings are inconsistent with those of Al-Shammari (2014), Elshandidy and Neri, (2015) who found a positive association and Al-Maghzom et al. (2016) who found a negative one and Elgammal et al. (2018) who find a no significant association.

The hypothesis $\mathrm{H} 2.3$ is rejected. The findings are inconsistent with the agency and entrenchment theory. The results are consistent with Elzahar and Hussainey (2012), Mokhtar and Mellett (2013) and Elshandidy and Neri (2015) who found that there is no impact of CEO duality on voluntary risk reporting. However, there are inconsistent with the results of Mokhtar and Mellett (2013) regarding mandatory risk disclosure (a negative significant association) and also Al-Shammari (2014) who found a negative significant association between CEO duality and risk disclosure on annual reports of listed non-financial companies.

The results show a positive significant association between the quality of risk disclosure and the presence of women on the board at the $1 \%$ level. Hence, we accept H2.4. The results highlighted the contribution of women on the board to the disclosure of related risk information and hence the accountability. Berger et al. (2014), by using a comprehensive dataset of German bank directors, has shown that director age, gender, and educational qualifications influence organisational risky decision making. Prior literature considers that women on the board of directors could enhance the decision making process because there are considered less selfinterested which improve the board effectiveness (Coffey and Wang, 1998). In addition, women have the ability to enhance the quality of the board communications and are more likely to discuss some issues considered unpalatable by male boards (Clarke, 2005). In fact, they are considered more collaborative and provide greater disclosure to the stakeholders (Eagly et al., 2003) and their presence on the board could be translated to competitive advantage and contribute to better corporate governance (Bernardi et al., 2006). There are few studies that examined the association between the existence of women on the board and the disclosure. However, we can notice that our results are consistent with Allini et al. (2016). Nevertheless, Allini et al. (2014) found a negative association.

We found a positive significant association with the quality of risk disclosure and the presence of family members on the board. This result allows us to reject H2.5. Notably, there is no extensive literature examining the association between this variable and risk disclosure quality. However, we can note that our results are inconsistent with Al-Shammari (2014) who did not found an association between the CRD and the family members on the board.

\section{The audit committee structure}

The results report an insignificant association between the size of the audit committee and the risk disclosure quality. Accordingly, the hypothesis H3.1 is rejected. Through the literature, there is no theoretical explanation of this relationship. Our results are consistent with Elzahar and Hussainey (2012), Al-Maghzom et al. (2016). However, there are inconsistent with Barako et al. (2006) who found a positive relationship with corporate disclosure. 
In addition, a positive significant association at the $1 \%$ level between the independence of the audit committee and the quality of risk disclosure is revealed. Hence, we accept the hypothesis H3.2. This association can be justified with regard to agency theory. In fact, the presence of independent members on the audit committee will enhance the managers' control, consequently, reduce information asymmetry and enhance the protection of shareholders' interests. Our results are consistent with Taylor (2011), Oliveira et al. (2011) and Elshandidy et al. (2013).

\section{The type of the external auditor}

The coefficients related to the type of external auditor is positively but not significantly correlated with the quality of CRD. Hence, we reject the hypothesis H4. According to the agency theory, the external auditor plays a crucial role in mitigating conflicts of interest between managers and investors (Jensen and Meckling, 1976). In addition; he guarantees the reliability and credibility of voluntary disclosure (Deumes and Knechel, 2008). Companies with Big 4 auditor are more likely to be legitimated by the latter to provide better risk information in their annual reports (Hassan, 2009). Our findings are consistent with Elshandidy and Neri (2015), nevertheless, there are inconsistent with Elshandidy et al. (2013) and Abid and Shaiq (2015).

Regarding the control variables, we found that there is no impact on company size, dividendyield and industry type on the quality of risk disclosure. However, a negative significant association is revealed for profitability and leverage. In addition, a positive significant association is revealed between the liquidity and the risk disclosure quality. Hence, more profitable companies disclose less quality of risk-related information. Indeed, if we consider the impact of the disclosure of favourable information on competitive risk, the company can abstain spreading this information. Moreover, the more the firms are leveraged, the less they reveal their proprietary information to avoid bankruptcy. The restriction of the risk information dissemination by the manager will let him searching for the ways to manage this risk. (Miihkinen, 2012).

\section{The corporate risk disclosure and revolution}

The results showed that the impact of concentration ownership on the quality of risk disclosure decreased after the revolution. It is also the case of government ownership, family ownership, size of the audit committee. However, no change in the relationship between the quality of risk disclosure and the remainder corporate governance mechanisms.

The prior risk disclosure studies suffer from research scarcity on an uncertain context, particularly in developing countries that have witnessed the Arab spring, where investors become more averse to risk (Hemrit, 2018). However, the following results could be explained according to agency theory. In fact, when the ownership concentration is beyond certain thresholds, large shareholders often tend to expropriate minority shareholders and to create private benefits (Shleifer and Vishny, 1997). In other words, when the capital is distributed between some large shareholders, the communication of information is of little importance 
since the large shareholders have direct access to the information. In fact, the large shareholders usually resort to internal information' means in the company, and they are less dependent on formal communication' means intended to the other stakeholders. Furthermore, they may tend to protect their informative advantage to continue reaping private benefits particularly in the moment of crisis. Besides, in such context, the agency conflicts can arise between the government shareholders and the managers due to their interest divergence.

Indeed the aim of the managers differs from that of the governmental shareholders; in the sense that the latter is interested in the survival and the interests of the nation more than profit (Mak and $\mathrm{Li}, 2001$ ). Moreover, according to the positive accounting theory, individuals may act to enhance their own utility (Watt and Zimmerman, 1978).

\section{Conclusion}

We investigated the quality of risk disclosure in an emerging capital market. To do so, it was necessary to develop a new measure of risk disclosure quality on the Tunisian context. We used manual content analysis. Firstly, the descriptive statistics showed that the quality of risk disclosure in Tunisian companies for the period from 2008 to 2013 is weak. Secondly, the empirical results regarding the main analysis of the influence of corporate governance mechanisms on the quality of risk disclosure in Tunisian annual reports were mixed. We found that that the quality of risk disclosure is positively and significantly associated with institutional, independence of the directors, the presence of women on the board, the presence of family members on the board and the independence of audit committee. However, managerial ownership has a negative effect on risk disclosure quality. No impact was found regarding the impact of government ownership, family ownership, the board size, the CEO duality, the external auditor type and the size of the audit committee. We introduced the revolution as an interaction variable in order to assess if it has an impact on the relationship between corporate governance mechanisms and risk disclosure.

The main contribution of the study is the investigation on the influence of corporate governance mechanisms, on the risk disclosure quality using the Tunisian context. In fact, to the best of our knowledge, it is the first study that investigated the quality of risk disclosure for all Tunisian non-financial listed companies. Moreover, the studies about the quality of disclosure are scare and particularly regarding the risk disclosure. In addition, no study to the best of our knowledge has studied the quality of risk disclosure in Tunisia. Moreover, the study contributes to the literature by developing a new measure of risk disclosure quality adapted to the Tunisian context based on the IASB (2010) and the accounting firms' system (1997). Second, Tunisia is an emerging market, and the emerging markets are little studied with regard to risk disclosure. Furthermore, the third contribution is the investigation of these practices on a period of crisis (political crisis). Moreover, there was a need to better investigate the influence of corporate governance mechanisms on the risk disclosure, and we examined the influence of some variables that are little bit studied such as the presence of family members on the board of directors and the presence of women on the board. 
The findings of our study have theoretical and practical. On the one hand, theoretically, the findings of this research add to the existing literature on risk disclosure, particularly in the emerging context. Our measure for the quality of risk disclosure can be replicated in other contexts. Secondly, our results highlight the importance of corporate governance mechanisms on risk disclosure quality. The study also offers practical implications. In fact, the examination of the risk disclosure on the Tunisian listed companies could be helpful to the different stakeholders to assess the quality of risk reporting. The findings reveal a very little risk disclosure on Tunisian annual reports and a moderate quality of information. Hence, more consideration should be taken to impose regulations in term of risk disclosure and the quality of such information. In other words, it would be interesting to develop a framework for risk reporting practices and guidelines for Tunisian listed companies in order to satisfy the needs of the stakeholders and to allow them to make the appropriate assessment of the risk firm profile. In addition, the results show that some corporate governance mechanisms could influence the quality of risk disclosure. That may motivate the government and policymakers to give more importance to the implementation of good corporate governance in order to enhance the risk disclosure quality.

The study has a number of limitations. First, the sample size is relatively small. However, the small sample is justified by the fact that few non-financial Tunisian companies are listed and we find it difficult to examine other companies due to data availability. Second, we use the manual content analysis, which takes considerable time and efforts to score a sample of annual reports. Therefore, we restrict our analysis to one year only. Moreover, this study can be criticized for using only the annual reports as the only mean of communication. Regarding the measure of risk disclosure quality, we tried to develop an index adapted to the Tunisian context by referring to the Tunisian firms' accounting system (1997) and the IASB (2010). However, this index is restricted to the four qualitative attributes and it might be interesting to examine the tone of risk disclosure.

Our paper offers some lines for future research. It would be interesting to undertake crosscountry studies in order to make a comparison between countries and to enrich the understanding of the influence of the different regulatory, cultural and economic environments on the risk disclosure practices. For instance, we suggest future research to examine the risk disclosure among the other Arab countries especially those that were influenced by the "Arab Spring". Moreover, this study focused on the impact of corporate governance on the quality of risk disclosure and ignored the economic consequences. Hence, further research could investigate the relevance of the quality of risk disclosure and its impact on the cost of capital, firm value and analysts' earnings forecasts.

\section{Notes}

1. It should be noted that this law was strongly inspired under American law Sarbanes-Oxley (2002). 
2. It is a center within the Arab Institute of Entrepreneurs (IACE), which was established in 2009. Its mission is to encourage and enable business leaders, administrators and senior executives of the Tunisian public and private companies to add value to their organizations and adopt the most advanced practices in corporate governance and strengthening integrity. The CTGE work for a growing awareness of the importance of good corporate governance in maintaining investor confidence and sustainable performance improvement of the national economy" http://www.iace.tn/iace-centres/ctge/.

3. This definition for risk applies equally well regardless of whether we're talking about investment, market, credit, legal, insurance, or any of the other risk domains (including information risk) that are commonly dealt with in business, government, and life. In other words, the fundamental nature of risk is universal, regardless of context", An Introduction to Factor Analysis of Information Risk (FAIR), Risk Management Insight LLC, November 2006 Jack A. Jones, CISSP, CISM, CISA Jones (2006).

4. The risk that something will go wrong.

5. The risk associated with uncertainty which gives rise to the opportunity for gain as well as loss.

6. FRS5 "Reporting the Substance of Transactions", ASB 1994.

7. CMF is the Financial Market Council (Conseil du Marché Financier).

8. Law No. 2005-96 of 18 October 2005, s.15.

9. Article 51 (new), Title II, Chapter II related to the dynamization of the commercial register System.

10. Article 3 (new), Article 3a and Article 3b, Title II, Chapter III of the Law No. 2005-96 of 18 October 2005.

11. For example, the CMF issued a release on 8 Février 2010 entitled "Reminder to companies making public offerings: Activity Report" and recently a release on April 4th2016 "Reminder to companies admitted to exchange on the stock market" to remind the newly listed companies on the stock exchange of their disclosure obligations.

12. Code des Sociétés Commerciales (Code of Commercial Companies).

13. Beest and Braam (2012) defined financial reporting quality in terms of decision usefulness.

14. The scott's Pi test was also used by Linsley and Shrives (2006), Abraham and Cox (2007), Al-Shammari (2014) to measure inter-rater reliability.

15. Freelon (2010) and Lombard et al. (2010) state that ReCal software is useful to assess intercoder reliability.

16. We classified companies through their economic growth: high- and low growth firms (Hussainey and Walker, 2009). According to prior studies high growth firms are more 
motivated to disclose greater information to insiders in order to reduce information asymmetry and have more external financing (Khurana et al., 2006; Chavent et al., 2006; O'Sullivan et al., 2008). Moreover, Elshandidy et al (2013) assumed that firms with high growth are more likely to enhance their risk disclosure in order to provide signals to investors about these risks and their ability to manage them. For that, we calculated the mean of growth for each sector, and the median of growth for all industries. We considered that industries, which have a mean growth superior to the median, are high growth industry. For our sample consumer services, health, industrials and oil and gas are high growth sectors, however we consider telecommunications, consumer goods and basic material are low growth industry.

\section{REFERENCES}

Abdullah, M., Abdul Shukor, Z., Mohamed, Z. M., Ahmad, A. (2015). Risk management disclosure: A study on the effect of voluntary risk management disclosure toward firm value. Journal of Applied Accounting Research, 16(3), 400-432.

Abid. A., Shaiq. M. (2015). A Study of Risk Disclosures in the Annual Reports of Pakistani Companies: A Content Analysis. Research Journal of Finance and Accounting, 16(11), $14-24$

Abraham S., Cox, P (2007) Analyzing the determinants of narrative risk information in UK FTSE 100 annual reports. The British Accounting Review, 39(3), 227-248.

Abraham, S., Marston, C. and Darby, P. (2012). Risk reporting: clarity, relevance and location. Edinburgh: Institute of Chartered Accountants of Scotland.

Adams, R. B., Ferreira, D. (2009). Women in the boardroom and their impact on governance and performance. Journal of financial economics, 94(2), 291-309.

Agrawal, A., Knoeber, C. R. (1996). Firm performance and mechanisms to control agency problems between managers and shareholders. Journal of financial and quantitative analysis, 31(03), 377-397.

Agrawal, A., Mandelker, G. N. (1990). Large shareholders and the monitoring of managers: The case of antitakeover charter amendments. Journal of Financial and Quantitative analysis, 25(02), 143-161.

Agrawal, M., Sensarma, R. (2007). Determinants of merger activity: evidence from India. International Journal of Financial Services Management.

Ali, M. M., Taylor, D. (2014). Corporate risk disclosure in Malaysia: The influence of predispositions of chief executive officers and chairs of audit committee. Research Journal of Finance and Accounting, 5(2), 92-106.

Allegrini, M., \& Greco, G. (2013). Corporate boards, audit committees and voluntary disclosure: Evidence from Italian listed companies. Journal of Management \& Governance, 17(1), 187-216.

Allini, A., Manes Rossi, F., Hussainey, K. (2016). The board's role in risk disclosure: an exploratory study of Italian listed state-owned enterprises. Public Money and Management, 36(2), 113-120.

Allini, A., Rossi, F. M., Macchioni, R. (2014). Do corporate governance characteristics affect non-financial risk disclosure in government-owned companies? The Italian experience. Financial reporting. 
Al-Maghzom, A., Hussainey, K., Aly, D. A. (2016). Corporate Governance and Risk Disclosure: Evidence from Saudi Arabia. Corporate Ownership and Control Journal, 13(2), 145-166

Al-Moataz, E., Hussainey, K. (2012). Determinants of corporate governance disclosure in Saudi companies. Journal of Economics and Management, 5(1), 52-84.

Al-Shammari, B. (2014). Kuwait Corporate Characteristics and Level of Risk Disclosure: A Content Analysis Approach. Journal of Contemporary Issues in Business Research, $3(3), 128-153$.

Al-Shammari, B., Al-Sultan, W. (2010). Corporate governance and voluntary disclosure in Kuwait. International Journal of Disclosure and Governance, 7(3), 262-280.

Alzead, R., Hussainey, K. (2017). Risk disclosure practice in Saudi non-financial listed companies. Corporate Ownership and Control.

Amran, A., R.B. Abdul Manaf, and M.H. Bin CheHaat. (2008). Risk reporting: An exploratory study on risk management disclosure in Malaysian annual reports. Managerial Auditing Journal. 24(1), 39-57

Baek, H. Y., Johnson, D. R., \& Kim, J. W. (2009). Managerial ownership, corporate governance, and voluntary disclosure. Journal of Business and Economic Studies, $15(2), 44$.

Barakat, A., Hussainey, K. (2013) Bank governance, regulation, supervision, and risk reporting: Evidence from operational risk disclosures in European banks. International Review of Financial Analysis, 30, 254-273.

Barako, D. G., Hancock, P. Izan, H. Y. (2006). Factors influencing voluntary corporate disclosure by Kenyan companies. Corporate Governance: An International Review, 14(2), 107-125. CNRS

Baroma, B. (2014). The Association between the Level of Risk Disclosure and Corporation Characteristics in the Annual Reports of Egyptian Companies. American Journal of Business, Economics and Management, 2(1), 9.

Beasley, M. (1996). An Empirical Analysis of the Relationship between the Board of Director Composition and Financial Statement Fraud, The Accounting Review, 71(4), 443-465.

Beattie, V., B. McInnes, S. Fearnley., (2004). A Methodology for Analyzing and Evaluating Narratives in Annual Reports: A Comprehensive Descriptive Profile and Metrics for Disclosure Quality Attributes, Accounting Forum, 28(3), 205-236.

Beck, N. (2001), “Time-series-cross-section data”, Statistica Neerlandica, 55, 111-133.

Becht, M. (1997). Strong blockholders, weak owners and the need for European mandatory disclosure. The separation of ownership and control: A survey of 7 European countries.

Beekes, W., Brown, P. (2006). Do Better-Governed Australian Firms Make More Informative Disclosures?. Journal of Business Finance and Accounting, 33(3-4), 422-450.

Belgacem, I.Omri, A. (2014). The Value Relevance of Voluntary Disclosure: Evidence from Tunisia Stock Market. International Journal of Management, Accounting and Economics, 1(5), 353-370.

Beretta S. Bozzolan S. (2004). A framework for the analysis of firm risk communication. The International Journal of Accounting, 39(3), 265-288. 
Berger, A. N., Kick, T., Schaeck, K. (2014). Executive board composition and bank risk taking. Journal of Corporate Finance, 28, 48-65.

Bernardi, R. A., Bosco, S. M., Vassill, K. M. (2006). Does female representation on boards of directors associate with Fortune's " 100 best companies to work for' list? Business and Society, 45(2), 235-248.

Botosan, C. A. (2004). Discussion of a framework for the analysis of firm risk communication. The International Journal of Accounting, 39 (3), 289-295.

Braam, G., Van Beest, F. (2013). Conceptually-Based Financial reporting Quality Assessment. An Empirical Analysis on Quality Differences Between UK Annual Reports and US 10-K Reports. Journal of Modern Accounting and Auditing, 9 (10), 1281-1301

Bradbury, M., Mak, Y. Tan, S. (2006). Board characteristics, audit committee characteristics and abnormal accruals. Pacific Accounting Review, 18, 47-68.

Brown, P., Beekes, W., Verhoeven, P. (2011). Corporate governance, accounting and finance: A review. Accounting finance, 51(1), 96-172.

Bushee, B. J., Noe, C. F. (2000). Corporate disclosure practices, institutional investors, and stock return volatility. Journal of accounting research, 38, 171-202.

Byard, D., Li, Y. Weintrop, J. (2006) Corporate Governance and the Quality of Financial Analyst's Information, Journal of Accounting and Public Policy, 25, 609-625

Cadbury, A. (1992). The Committee on the Financial Aspects of Corporate Governance and Gee and Co. Ltd. Report, 61.

Carcello, J. V., Neal, T. L. (2000). Audit committee composition and auditor reporting. The Accounting Review, 75(4), 453-467.

Cerbioni, F., Parbonetti, A. (2007). Exploring the effects of corporate governance on intellectual capital disclosure: an analysis of European biotechnology companies. European Accounting Review, 16(4), 791-826.

Chakroun, R. (2013). Relation entre l'étendue de la divulgation volontaire et les mécanismes internes de gouvernance: Substitution ou complémentarité ?, Revue Marocaine de Comptabilité, Contrôle et Audit, n²1, avril 2013, p.89-126

Chakroun, R., Hussainey, K. (2014). Disclosure quality in Tunisian annual reports. Corporate Ownership and Control, 11(4), 58-80

Chakroun, R., Matoussi, H. (2010). Confrontation Entre L'Offre et La Demande D'Informations Volontaires Au Niveau Des Rapports Annuels Dans Un Pays Emergent: Cas De La Tunisie. In Crises et nouvelles problématiques de la Valeur (pp. CD-ROM).

Charreaux, G. (1985). Le dilemme des PME: ouvrir son capital ou s'endetter. Revue française de gestion, 59-72.

Chau, G.K., S.J. Gray (2002). Ownership structure and corporate voluntary disclosure in Hong Kong and Singapore. The International Journal of Accounting, 37(2), 247-265.

Chavent, M., Ding, Y., Fu, L., Stolowy, H., Wang, H. (2006). Disclosure and determinants studies: An extension using the divisive clustering method (DIV). European Accounting Review, 15(2), 181-218.

Chen, C., B. Jaggi, (2000) "Association Between Independent Non-Executive Directors, Family control and Financial Disclosures in Hong Kong”, Journal of Accounting and Public Policy, 19, 285-310. 
Cheng, C., Courtenay, M. (2006) "Board Composition, Regulatory Regime and Voluntary Disclosure". The International Journal of Accounting, 41, 262-289.

Chung, R., Firth, M., Kim, J., 2002. Institutional monitoring and opportunistic earnings management. Journal of Corporate Finance, 8(1), 29-48.

Clarke, C. J. 2005. The XX factor in the boardroom: Why women make better directors. Directors Monthly (August), 12-14.

Coffey, B. S., Wang, J. (1998). Board diversity and managerial control as predictors of corporate social performance. Journal of Business Ethics, 17(14), 1595-1603.

Cooke, T.E. (1998), Regression analysis in accounting disclosure studies, Accounting and Business Research, 28 (3), 209-24.

Core, J. E. (2001). A review of the empirical disclosure literature: discussion. Journal of Accounting and Economics, 31(1), 441-456.

Cormier, D., Ledoux, M. J., Magnan, M., Aerts, W. (2010). Corporate governance and information asymmetry between managers and investors. Corporate Governance: The international journal of business in society, 10(5), 574-589.

Cornett, M. M., Guo, L., Khaksari, S., Tehranian, H. (2010). The impact of state ownership on performance differences in privately-owned versus state-owned banks: An international comparison. Journal of Financial Intermediation, 19(1), 74-94.

Davis, J. H., Schoorman, F. D., Donaldson, L. (1997). Toward a stewardship theory of management. Academy of Management review, 22(1), 20-47.

Demsetz, H., Lehn, K. (1985). The structure of corporate ownership: Causes and consequences. Journal of political economy, 93(6), 1155-1177.

Deumes R., (2008) Corporate risk reporting: A content analysis of narrative risk disclosures in Prospectuses. Journal of Business Communication, 45(2), 120-157.

Deumes R., W. R. Knechel, (2008) Economic Incentives for Voluntary Reporting on Internal Risk Management and Control Systems. Auditing: A Journal of Practice and Theory, 27(1), 35-66.

Diamond, D. W., \& Verrecchia, R. E. (1991). Disclosure, liquidity, and the cost of capital. The journal of Finance, 46(4), 1325-1359.

Diouani, B., Khlif, W. (2013). Comportement du dirigeant et décision de divulgation volontaire d'informations: cas du marché tunisien. International Management, 17(4), 34-49.

Dobler, M. (2008). Incentives for risk reporting: A discretionary disclosure and cheap talk approach. The International Journal of Accounting, 43(2), 184-206.

Donaldson, L., Davis, J. H. (1991). Stewardship theory or agency theory: CEO governance and shareholder returns. Australian Journal of management, 16(1), 49-64.

Eagly, A. H., Johannesen-Schmidt, M. C., Van Engen, M. L. (2003). Transformational, transactional, and laissez-faire leadership styles: a meta-analysis comparing women and men. Psychological bulletin, 129(4), 569.

Elgammal, M. M., Hussainey, K., Ahmed, F. (2018). Corporate governance and voluntary risk and forward-looking disclosures. Journal of Applied Accounting Research, 19(4), 592-607. 
Elshandidy, T., Neri, L. (2015). Corporate governance, risk disclosure practices, and market liquidity: comparative evidence from the UK and Italy. Corporate Governance: An International Review, 23(4), 331-356.

Elshandidy, T., Fraser, I., Hussainey, K. (2013). Aggregated, voluntary, and mandatory risk disclosure incentives: Evidence from UK FTSE all-share companies. International Review of Financial Analysis, 30, 320-333.

Elshandidy, T., Neri, L., Guo, Y. (2018). Determinants and impacts of risk disclosure quality: evidence from China. Journal of Applied Accounting Research, 19(4), 518-536.

Elzahar, H., Hussainey, K. (2012). Determinants of narrative risk disclosures in UK interim reports. The Journal of Risk Finance, 13(2), 133-147.

Eng, L. L., Mak, Y. T. (2003). Corporate governance and voluntary disclosure. Journal of accounting and public policy, 22(4), 325-345.

Erhardt, N. L., Werbel, J. D., Shrader, C. B. (2003). Board of director diversity and firm financial performance. Corporate governance: An international review, 11(2), 102111.

Fama, E. F., Jensen, M. C. (1983). Separation of ownership and control. The Journal of Law Economics, 26(2), 301-325.

Fama, E. F., Jensen, M. C. (1985). Organizational forms and investment decisions. Journal of financial Economics, 14(1), 101-119.

Firth, M., P. M. P. Fung, O. M. Rui, (2007), "Ownership, two-tier board structure, and the informativeness of earnings-Evidence from China", Journal of Accounting and Public Policy, 26, 463-496

Freelon, D. G. (2010). ReCal: Intercoder reliability calculation as a web service. International Journal of Internet Science, 5(1), 20-33.

Gulko, N., Hyde, C., Seppala, N. (2017). Disclosure of corporate risks and governance before, during and after the global financial crisis: case study in the UK construction industry in 2006-2009. International Journal of Disclosure and Governance, 1-17.

Haniffa, R. M., Cooke, T. E. (2002). Culture, corporate governance and disclosure in Malaysian corporations. Abacus, 38(3), 317-349.

Hassan, K. M. (2009). UAE corporations-specific characteristics and level of risk disclosure. Managerial Auditing Journal, 24(7), 668-687.

Hassan, M. K. (2014). Risk narrative disclosure strategies to enhance organizational legitimacy: Evidence from UAE financial institutions. International Journal of disclosure and Governance, 11(1), 1-17.

Healy, P. M., Hutton, A. P., Palepu, K. G. (1999). Stock performance and intermediation changes surrounding sustained increases in disclosure. Contemporary accounting research, 16(3), 485-520.

Heinle, M. S., Smith, K. C. (2017). A theory of risk disclosure. Review of Accounting Studies, 22(4), 1459-1491.

Hemrit, W. (2018). Risk reporting appraisal in post-revolutionary Tunisia. Journal of Financial Reporting and Accounting, 16(4), 522-542.

Hidalgo, R., García-Meca, E. and Martínez, I. (2011). Corporate governance and intellectual capital disclosure. Journal of Business Ethics, 100 (3), 483-495. 
Higgs, D. (2003). Independent Review of Non-Executive Directors. Higgs Report. ICAEW

Hillman, A. J., Shropshire, C., Cannella, A. A. (2007). Organizational predictors of women on corporate boards. Academy of Management Journal, 50(4), 941-952.

Ho, S.S.M., Wong, K.S., (2001). A study of the relationship between corporate governance structure and the extent of voluntary disclosure. Journal of International Accounting Auditing Taxation, 10 (2), 139-156.

Hopkins, P. (1996). The effect of financial statement classification of hybrid financial instruments on financial analysts stock price judgements. Journal of Accounting Research, 34, 33-50.

Hsiao, C. (2014). Analysis of panel data (No. 54). Cambridge university press.

Huafang, X., Jianguo, Y. (2007). Ownership structure, board composition and corporate voluntary disclosure: Evidence from listed companies in China. Managerial Auditing Journal, 22(6), 604-619.

Hussainey, K., Walker, M. (2009). The effects of voluntary disclosure and dividend propensity on prices leading earnings. Accounting and Business Research, 39(1), 37-55.

Jensen M.C. (1993). The Modern Industrial Revolution, Exit, and the Failure of Internal Control Systems", Journal of Finance, 48 (3), 831-880.

Jensen, M.C., Meckling, W.H., (1976). Theory of the firm; managerial behavior, agency costs and ownership structure, Journal of Financial Economics, 3(4), 305-360.

John, K., Senbet, L. W. (1998). Corporate governance and board effectiveness. Journal of Banking and Finance, 22(4), 371-403.

Jones, J., 2006. An introduction to factor analysis of information risk. Norwich Journal of Information Assurance, 2(1): 67 1-76.

Kalbers, L. P., Fogarty, T. J. (1993). Audit committee effectiveness: An empirical investigation of the contribution of power. Auditing, 12(1), 24.

Kent, P., Stewart, J. (2008). Corporate governance and disclosures on the transition to international financial reporting standards. Accounting and Finance, 48(4), 649-671.

Khalil, A., Maghraby, M. (2017). The determinants of internet risk disclosure: empirical study of Egyptian listed companies. Managerial Auditing Journal, 32(8), 746-767.

Khlif, H., Hussainey, K. (2016).The association between risk disclosure and firm characteristics: a meta-analysis. Journal of Risk Research, 19(2), 181-211.

Khlif, H., Souissi, M. (2010). The determinants of corporate disclosure: a metaanalysis. International Journal of Accounting \& Information Management, 18(3), 198-219.

Khurana, I., R. Pereira, X. Martin. 2006. Firm growth and disclosure: An empirical analysis. Journal of Financial and Quantitative Analysis, 41 (2), 357-380.

Kim, A.K., Kitsabunnarat-Chatjuthamard, P. and Noftsinger, J.R (2007) Large shareholders, board independence and minority shareholders rights; Evidence from Europe". Journal of Corporate Finance, 13, 859-80.

King Committee on Corporate Governance, Institute of Directors (South Africa). (2002). King Report on Corporate Governance for South Africa, 2002. Institute of Directors in Southern Africa. 
Klein, A. (2002). Audit committee, board of director characteristics, and earnings management. Journal of accounting and economics, 33(3), 375-400.

Konishi, N., Mohobbot, A. (2007). Risk reporting of Japanese companies and its association with corporate characteristics. International Journal of Accounting, Auditing and Performance Evaluation, 4(3), 263-285.

Kothari, S. P., J. L. Zimmerman. (1995). Price and return models. Journal of Accounting and Economics, 20 (2), 155-192.

Krippendorff, K. (1980), Content Analysis: An Introduction to Its Methodology, Sage Publications, Newbury Park, CA.

Lajili, K. (2009). Corporate risk disclosure and corporate governance. Journal of Risk and Financial Management, 2(1), 94-117.

Leitner-Hanetseder, S. (2012). Quality and determinants of risk reporting: evidence from Germany and Austria. Available at SSRN 1735586.

Leung S., B. Horwitz (2004).Director ownership and voluntary segment disclosure: Hong Kong evidence. Journal of International Financial, Management and Accounting, 15 (3): 235-260.

Li, J., Pike, R., Haniffa, R. (2008). Intellectual capital disclosure and corporate governance structure in UK firms. Accounting and Business Research, 38(2), 137-159.

Linsley, P., Shrives, P. (2005). Examining risk reporting in UK public companies. The Journal of Risk Finance, 6(4), 292-305.

Linsley, P., Shrives, P. (2006). Risk reporting: A study of risk disclosure in the annual reports of UK companies. The British Accounting Review, 38(4), 387-404.

Lombard, M., Snyder-Duch, Bracken. (2010). Practical resources for assessing and reporting intercoder reliability in content analysis research projects. http://matthewlombard.com/reliability/.

Maffei, M., Aria, M., Fiondella, C., Spanò, R., \& Zagaria, C. (2014). (Un) useful risk disclosure: explanations from the Italian banks. Managerial Auditing Journal, 29(7), 621-648.

Mak, Y. T., Li, Y. (2001).Determinants of corporate ownership and board structure: evidence from Singapore. Journal of Corporate Finance, 7(3), 235-256.

Makhaiel, N. K. B., Sherer, M. L. J. (2018). The effect of political-economic reform on the quality of financial reporting in Egypt. Journal of Financial Reporting and Accounting, 16(1), 245-270.

Makhija, A.K., Patton, J.M., (2004). The impact of firm ownership structure on voluntary disclosure: Empirical evidence from Czech annual reports. Journal of Business, 77(3), 457-492.

Mangena, M., Pike, R. (2005). The effect of audit committee shareholding, financial expertise and size on interim financial disclosures. Accounting and Business Research, 35(4), 327-349.

Marshall, A., Weetman, P. (2007). Modelling transparency in disclosure: the case of foreign exchange risk management. Journal of Business Finance Accounting, 34(5-6), 705739.

Marston, C. L., P. J. Shivres, (1991).The use of disclosure indices in accounting research: A review article. British Accounting Review, 23(3), 195 - 210 
Martikainen, M., Kinnunen, J., Miihkinen, A., Troberg, P. (2015). Board's financial incentives, competence, and firm risk disclosure: Evidence from Finnish index listed companies. Journal of Applied Accounting Research, 16(3), 333-358.

Marzouk, M. (2016). Risk reporting during a crisis: evidence from the Egyptian capital market. Journal of Applied Accounting Research, 17(4), 378-396.

Meier, H.H., Tomaszewski, S.G., Tobing, R. (1995), Political risk assessment and disclosure in annual financial reports: the case of the Persian gulf war, Journal of International Accounting, Auditing and Taxation, 4 (1), 49-68.

Miihkinen A. (2012). What drives quality of firm risks disclosure? : The impact of a national disclosure standard and reporting incentives under IFRS. The International Journal of Accounting, 47 (4), 437-468.

Miihkinen, A. (2013). The usefulness of firm risk disclosures under different firm riskiness, investor-interest, and market conditions: New evidence from Finland. Advances in Accounting, 29(2), 312-331.

Mohd Ghazali, N. A. (2007). Ownership structure and corporate social responsibility disclosure: some Malaysian evidence. Corporate Governance: The international journal of business in society, 7(3), 251-266.

Mohd Ghazali, N.A., Weetman P., (2006). Perpetuating traditional influences: Voluntary disclosure in Malaysia. Journal of International Accounting Auditing and Taxation, 15 (2), 226-248.

Mohd-Nasir, N. and Abdulah, S.N. (2004). Voluntary disclosure and corporate governance among financially distressed listed firms in Malaysia. Financial Reporting, Regulation and Governance, 1(1), 95-139,

Mohobbot, A. (2005). Corporate risk reporting practices in annual reports of Japanese companies. Japanese Journal of Accounting, 16(1), 113-133

Mokhtar, E.S., Mellett, H., (2013) Competition, corporate governance, ownership structure and risk reporting, Managerial Auditing Journal, 28 (9), 838 - 865.

Moumen, N., Othman, H. B., Hussainey, K. (2015). The value relevance of risk disclosure in annual reports: Evidence from MENA emerging markets. Research in International Business and Finance, 34, 177-204.

Moumen, N., Othman, H. B., Hussainey, K. (2016). Board structure and the informativeness of risk disclosure: Evidence from MENA emerging markets. Advances in Accounting, 34, 82-97.

Mousa, G., Elamir, E. (2013). Content analysis of corporate risk disclosure: the case of Bahraini capital market. Global Review of Accounting and Finance, 4(1), 27-54.

Nagar, V., Nanda, D., Wysocki, P. (2003)."Discretionary disclosure and stock-based incentives". Journal of accounting and economics, 34(1), 283-309.

Ntim, C. G., Lindop, S., Thomas, D. A. (2013), Corporate governance and risk reporting in South Africa. International Review of Financial Analysis, 30, 363-383.

O’Sullivan, M., Percy, M., Stewart, J. (2008). Australian evidence on corporate governance attributes and their association with forward-looking information in the annual report. Journal of Management \& Governance, 12(1), 5-35. 
Oliveira, J., Rodrigues, L. L., Craig, R. (2013). Company Risk-related Disclosures in a Code Law Country: A Synopsis. Australasian Accounting Business and Finance Journal, $7(1), 123$.

Oliveira, J., Rodrigues, L., Craig, R. (2011). Voluntary risk reporting to enhance institutional and organizational legitimacy: Evidence from Portuguese banks. Journal of Financial Regulation and Compliance, 19(3), 271-289.

Owusu-Ansah, S. (1998). The impact of corporate attributes on the extent of mandatory disclosure and reporting by listed companies in Zimbabwe. The International Journal of Accounting, 33 (5), 605-31.

Patelli, L., Prencipe, A. (2007). The relationship between voluntary disclosure and independent directors in the presence of a dominant shareholder. European Accounting Review, $16(1), 5-33$.

Persons, O. S. (2009). Audit committee characteristics and earlier voluntary ethics disclosure among fraud and no-fraud firms. International Journal of Disclosure and Governance, 6(4), 284-297.

Pfeffer, J. (1972). Size and composition of corporate boards of directors: The organization and its environment. Administrative science quarterly, 218-228.

Probohudono, A., Tower, G. and Rusmin, R. (2013), Diversity in risk communication, Australasian Accounting Business and Finance Journal, 7 (1), 43-58.

Ruland, W., Tung, S., George, N. E. (1990)."Factors associated with the disclosure of managers' forecasts". Accounting Review, 710-721.

Saggar, R., Singh, B. (2017). Corporate governance and risk reporting: Indian evidence. Managerial Auditing Journal, 32(4/5), 378-405.

Said Mokhtar, E., Mellett, H. (2013). Competition, corporate governance, ownership structure and risk reporting. Managerial Auditing Journal, 28(9), 838-865.

Samaha, K., Khlif, H., Hussainey, K. (2015). The impact of board and audit committee characteristics on voluntary disclosure: A meta-analysis. Journal of International Accounting, Auditing and Taxation, 24, 13-28.

Schadewitz, H. J., Blevins, D. R. (1998).Major determinants of interim disclosures in an emerging market. American Business Review, 16(1), 41-55.

Schleicher, T., Walker, M. (2010). Bias in the tone of forward-looking narratives. Accounting and business research, 40(4), 371-390.

Sciascia, S., Mazzola, P. (2008). Family involvement in ownership and management: Exploring nonlinear effects on performance. Family Business Review, 21(4), 331-345.

Sepasi, S., Kazempour, M., Mansourlakoraj, R. (2016). Ownership Structure and Disclosure Quality: Case of Iran. Procedia Economics and Finance, 36, 108-112.

Shleifer, A., Vishny, R. W. (1986). Large shareholders and corporate control. The Journal of Political Economy, 461-488.

Singh, M., Mathur, I., Gleason, K. (2004), Governance and performance implications of diversification strategies: evidence from large US firms, Financial Review, 39, 489526.

Solomon, J. F. (1999). Do institutional investors in the UK adopt a dual strategy for managing foreign exchange risk? British Accounting Review, 31, 205-224. 
Solomon, J. F., Solomon, A., Norton, S. D., Joseph, N. L. (2000). A conceptual framework for corporate risk disclosure emerging from the agenda for corporate governance reform. The British Accounting Review, 32(4), 447-478.

Sridharan, U. V. (1996). CEO influence and executive compensation. Financial Review, 31(1), 51-66.

Srinidhi et al., (2011). Female directors and earnings quality. Contemporary Accounting Research, 28(5), 1610-1644.

Tauringana, V., Chithambo, L. (2016). Determinants of risk disclosure compliance in Malawi: a mixed-method approach. Journal of Accounting in Emerging Economies, 6(2), 111137.

Taylor, D. (2011). Corporate risk disclosures: the influence of institutional shareholders and the audit committee. Journal of Corporate Finance, Vol. 9, No. 1, pp.1-27.

Taylor, G., Tower, G., Neilson, J. (2010). Corporate communication of financial risk. Accounting and Finance, 50(2), 417-446.

Warfield, T. D., Wild, J. J., Wild, K. L. (1995). Managerial ownership, accounting choices, and informativeness of earnings. Journal of accounting and economics, 20(1), 61-91.

Watts, R. L., Zimmerman, J. L. (1983). Agency problems, auditing, and the theory of the firm: Some evidence. The Journal of Law and Economics, 26(3), 613-633.

White, H. (1980). A heteroskedasticity-consistent covariance matrix estimator and a direct test for heteroskedasticity. econometrica, 48(4), 817-838.

Williams, R. J. (2003). Women on corporate boards of directors and their influence on corporate philanthropy. Journal of Business Ethics, 42(1), 1-10.

Xiao, J. Z., Yang, H., Chow, C. W. (2004). The determinants and characteristics of voluntary Internet-based disclosures by listed Chinese companies. Journal of accounting and public policy, 23(3), 191-225.

Zaman, M., Hudaib, M., Haniffa, R. (2011). Corporate governance quality, audit fees and nonaudit services fees. Journal of Business Finance and Accounting, 38(1-2), 165-197.

Zimmerman, D. W. (1995). Increasing the power of nonparametric tests by detecting and downweighting outliers. The Journal of Experimental Education, 64(1), 71-78.

Zimmerman, D. W. (1998). Invalidation of parametric and nonparametric statistical tests by concurrent violation of two assumptions. The Journal of experimental education, 67(1), 55-68. 
Table 1. Firms' sample

\begin{tabular}{|c|c|c|c|c|c|c|}
\hline & 2008 & 2009 & 2010 & 2011 & 2012 & 2013 \\
\hline Available reports & 22 & 26 & 30 & 30 & 28 & 27 \\
\hline Missing reports & 10 & 6 & 2 & 2 & 4 & 5 \\
\hline $\begin{array}{l}\text { Reports of firms not listed on the } \\
\text { whole period }\end{array}$ & 1 & 0 & 4 & 4 & 2 & 3 \\
\hline \multicolumn{7}{|c|}{ Total of the analyzed reports from 2008 to $2013=152$} \\
\hline $\begin{array}{l}\text { Initial sample }=148 \\
(-) \text { Outliers }=33 \\
\text { Final sample }=115\end{array}$ & & & & & & \\
\hline
\end{tabular}

Table 2. Firms' industry sectors

\begin{tabular}{lcc}
\hline Sectors & $\begin{array}{c}\text { Number of } \\
\text { firms }\end{array}$ & $\begin{array}{c}\text { Frequency } \\
\text { \% }\end{array}$ \\
\hline Telecommunications & 2 & 6.25 \\
Consumer services & 4 & 12.5 \\
-General retailers & 1 & 3.125 \\
-Travel and leisure & 2 & 6.25 \\
Health & & \\
Consumer goods & 5 & 15.625 \\
-Automobiles and parts & 4 & 12.5 \\
-Food and Beverage & 1 & 3.125 \\
-Personal and household goods & & \\
Industrials & 6 & 18.75 \\
-Construction and materials & 2 & 6.25 \\
-Industrial goods and services & & \\
Basic Material & 3 & 9.375 \\
-Chemicals & 1 & 3.125 \\
-Raw materials & 1 & 3.125 \\
Oil and Gas & 32 & 100 \\
\hline TOTAL &
\end{tabular}

${ }^{1}$ We have to note that in order to ensure that all the companies were listed on all the period of the analysis 2008 2013, we removed 4 companies from the 32 companies. Hence, the total number of listed firms are 28 firms. 
Table 3. Risk disclosure quality index

\begin{tabular}{|cc|}
\hline Relevance & $\begin{array}{c}\text { If there are forward-looking } \\
\text { information } 1, \text { otherwise } 0\end{array}$ \\
\hline Faithful representation & Explanation 1, otherwise 0 \\
\hline Understandability & Graphs or tables 1, \\
& No graphs and tables 0 \\
\hline Comparability & In time and Space 1, otherwise 0 \\
\hline
\end{tabular}

Table 4. Descriptive statistics for the disclosure quality and the attributes

\begin{tabular}{|l|c|c|c|c|c|}
\hline Variable & Obs & Mean & S.D & Min & Max \\
\hline Qual & 115 & 6.8956 & 4.2722 & 1 & 18 \\
\hline Relev & 115 & .4521 & .8710 & 0 & 4 \\
\hline Faith & 115 & 4.7304 & 2.7316 & 1 & 11 \\
\hline Under & 115 & 1.5304 & 1.2726 & 0 & 6 \\
\hline Comp & 115 & .1826 & .4881 & 0 & 2 \\
\hline
\end{tabular}

Table 5. Descriptive statistics for independent continuous variables for 2008-2013

\begin{tabular}{llllll}
\hline Variable & Obs & Mean & S.D & Min & \multicolumn{1}{c}{ Max } \\
\hline Conc & 120 & .6887 & .1411 & .401 & .9678 \\
Mo & 120 & .1562 & .1925 & 0 & .735 \\
Inst & 120 & .1554 & .1528 & 0 & .5439 \\
Gov & 120 & .1232 & .2213 & 0 & .7442 \\
Famo & 120 & .3461 & .3126 & 0 & .8881 \\
Outsdr & 120 & .2905 & .1913 & 0 & .75 \\
Size_Bd & 120 & 8.65 & 2.1872 & 4 & 12 \\
Women & 120 & .0489 & .0880 & 0 & .375 \\
Famd & 120 & .2436 & .2540 & 0 & .7142 \\
Size_Ac & 120 & 2.9916 & .5575 & 0 & 4 \\
Ind_Ac & 120 & .0930 & .1466 & 0 & .3333 \\
Size_Comp & 120 & 7.9143 & .4668 & 6.2374 & 9.2495 \\
Prof & 120 & 4.6840 & 7.2922 & -19.6154 & 21.2857 \\
Lev & 120 & 54.8113 & 38.7905 & 5.7466 & 277.207 \\
Liquid & 120 & 2.1348 & 1.5772 & .3672 & 9.3967 \\
Divd & 120 & .0285 & .0241 & 0 & .1286 \\
\hline
\end{tabular}


Table 6. Descriptive statistics for dummy variables for 2008-2013

\begin{tabular}{lcll}
\hline & Obs. & Number & Proportion \% \\
\hline Dual & \multirow{2}{*}{120} & 36 & 30 \\
$\mathbf{0}$ & & 84 & 70 \\
$\mathbf{1}$ & & & \\
Exaud_Q & \multirow{2}{*}{120} & 83 & 68.33 \\
$\mathbf{0}$ & & 37 & 31.66 \\
$\mathbf{1}$ & & & \\
Indus & 120 & 62 & 51.66 \\
$\mathbf{0}$ & & 58 & 48.33 \\
$\mathbf{1}$ & & & \\
\hline
\end{tabular}


Table 7. Spearman correlations

\begin{tabular}{|c|c|c|c|c|c|c|c|c|c|c|c|c|c|c|c|c|}
\hline & 巳̈ & 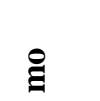 & $\underline{\underline{\hat{y}}}$ & 家 & 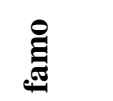 & 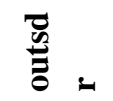 & 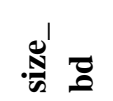 & छ & 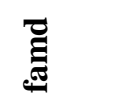 & 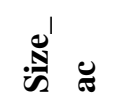 & 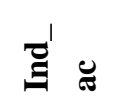 & 胥 & $\ddot{\circ}$ & e & ${ }^{\Xi} \cdot \vec{\Xi}$ & $\stackrel{\vec{Z}}{:}$ \\
\hline Conc & 1.0000 & -0.0913 & -0.0514 & -0.0758 & $0.3523 *$ & 0.0762 & 0.0865 & 0.0117 & $0 . .2729^{*}$ & $-0.1797^{*}$ & -0.0094 & $0.2916^{*}$ & $0.2466^{*}$ & $0.2264 *$ & $-0.3451^{*}$ & -0.1087 \\
\hline Mo & & 1.0000 & -0.0739 & -0.0039 & 0.0908 & -0.1571 & $-0.2508^{*}$ & $0.2576^{*}$ & 0.1138 & 0.0265 & 0.1346 & -0.0119 & 0.0596 & 0.0420 & 0.0159 & 0.1143 \\
\hline Inst & & & 1.0000 & 0.1057 & $-0.3833^{*}$ & 0.0619 & $0.3385^{*}$ & 0.0276 & $-0.3343 *$ & $0.1991^{*}$ & -0.0737 & $0.4103^{*}$ & -0.1612 & $0.2362 *$ & -0.1097 & 0.0269 \\
\hline Gov & & & & 1.0000 & $-0.4756^{*}$ & $0.3949^{*}$ & $0.3452 *$ & $0.4285^{*}$ & $-0.3515^{*}$ & 0.1792 & $0.2065^{*}$ & -0.0871 & -0.0887 & $-0.2002 *$ & 0.1532 & 0.0473 \\
\hline Famo & & & & & 1.0000 & -0.0864 & $-0.3433^{*}$ & -0.1742 & $0.6233^{*}$ & -0.1448 & -0.0594 & $0.2105^{*}$ & 0.1714 & $0.2553 *$ & $-0.3714^{*}$ & -0.0335 \\
\hline Outsdr & & & & & & 1.0000 & $0.3981 *$ & $0.2624 *$ & $0 . .1082$ & 0.1331 & $0.2680^{*}$ & 0.1348 & 0.1088 & $-0.1875^{*}$ & 0.0520 & 0.0791 \\
\hline size_bd & & & & & & & 1.0000 & $0.3043 *$ & $-0.2119^{*}$ & 0.1012 & -0.0426 & $0.2182 *$ & 0.0248 & -0.0221 & 0.0381 & 0.0890 \\
\hline Women & & & & & & & & 1.0000 & -0.1510 & $0.1839^{*}$ & -0.0150 & 0.1593 & -0.0590 & -0.0066 & -0.0765 & -0.0761 \\
\hline Famd & & & & & & & & & 1.0000 & -0.1294 & $0.2671 *$ & 0.1362 & $0.1898 *$ & 0.0201 & -0.1766 & 0.0761 \\
\hline size_ac & & & & & & & & & & 1.0000 & 0.1717 & -0.0570 & 0.0102 & 0.0540 & 0.0765 & 0.0332 \\
\hline ind_ac & & & & & & & & & & & 1.0000 & -0.1137 & 0.1613 & $-0.2761^{*}$ & $0.2794 *$ & 0.1672 \\
\hline size_comp & & & & & & & & & & & & 1.0000 & 0.0112 & $0.4722 *$ & $-0.4887 *$ & -0.0056 \\
\hline Prof & & & & & & & & & & & & & 1.0000 & $-0.4918^{*}$ & $0.4622 *$ & $0.5885^{*}$ \\
\hline Lev & & & & & & & & & & & & & & 1.0000 & $-0.7489^{*}$ & $-0.4291 *$ \\
\hline Liquid & & & & & & & & & & & & & & & 1.0000 & $0.5010^{*}$ \\
\hline Divd & & & & & & & & & & & & & & & & 1.0000 \\
\hline
\end{tabular}

The significance levels (two-tail test) are: $*=10 \%, * *=5 \%$ and $* * *=1 \%$. 
Table 8. Poisson Regression Results

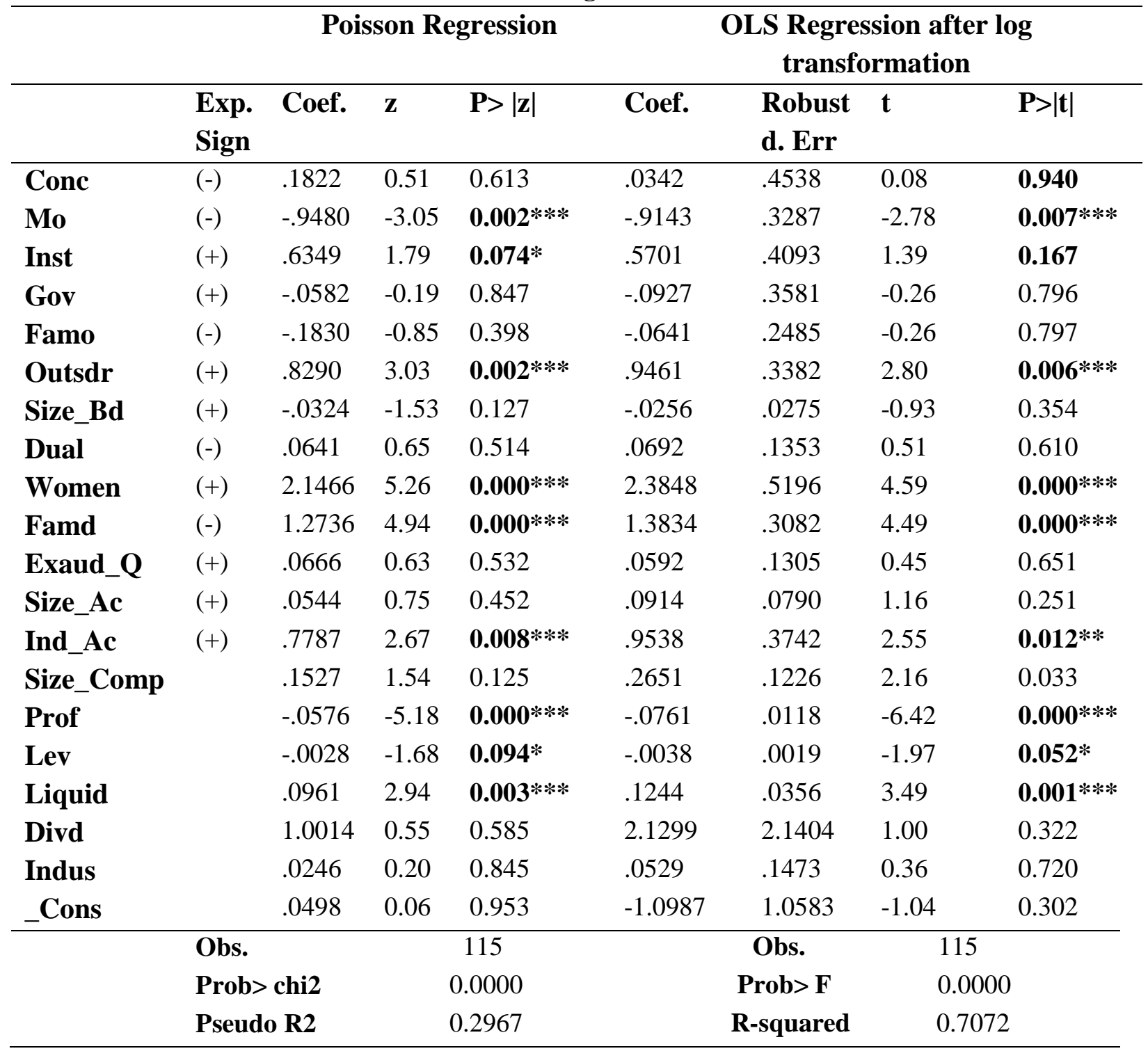

The significance levels (two-tail test) are: $*=10 \%$, $* *=5 \%$ and $* * *=1 \%$. 
Table 9. The impact of the revolution on the relationship between the quality of CRD and corporate governance

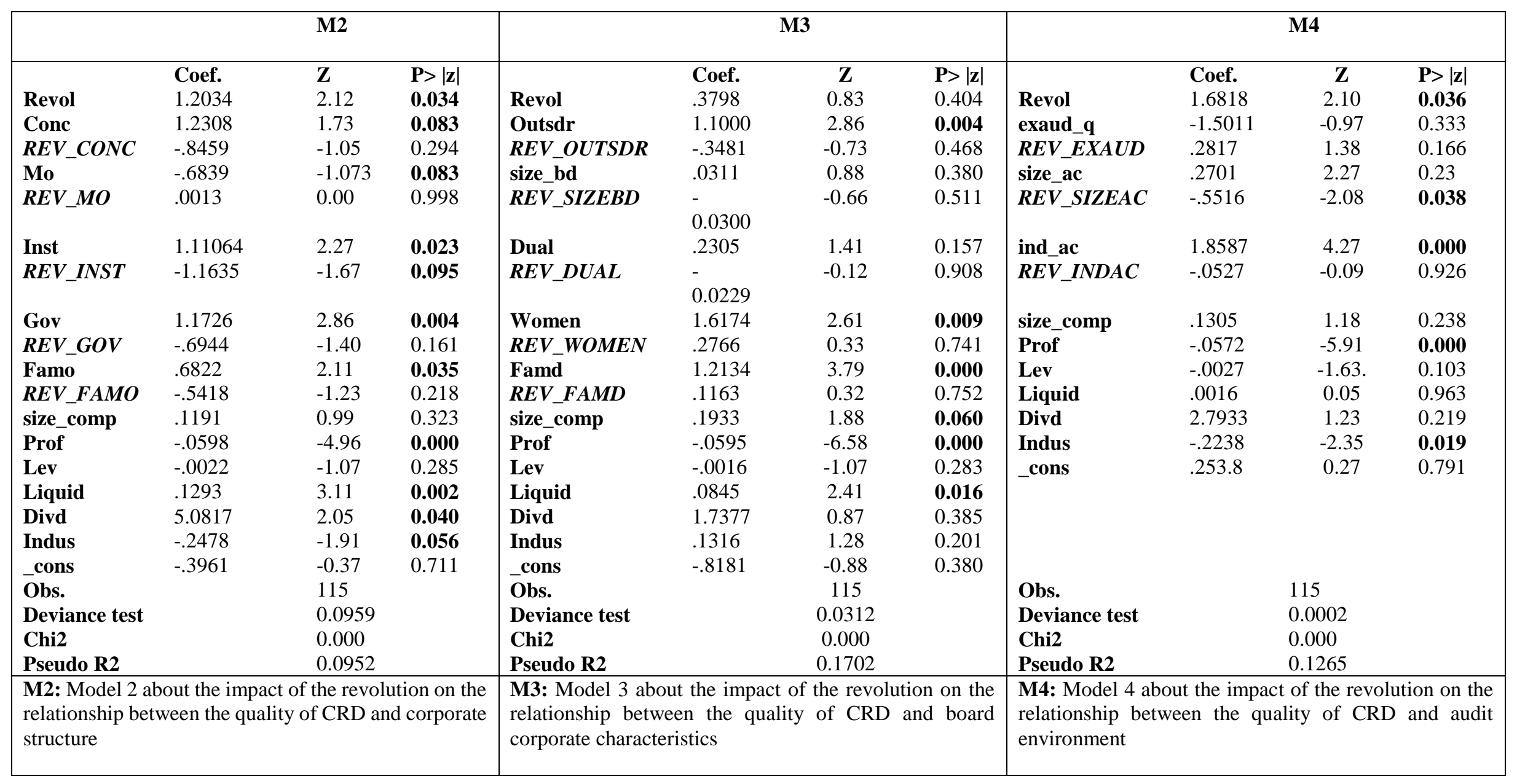

